\title{
CONTROLLING THE OPERATION PROCESS OF THE UNMANNED AERIAL SYSTEM
}

\section{STEROWANIE PROCESEM EKSPLOATACJI TECHNICZNEJ BEZZALOGOWEGO SYSTEMU POWIETRZNEGO}

\section{Leszek Ulanowicz, Michał Jóźko, Paweł Szczepaniak}

Air Force Institute of Technology, Instytut Techniczny Wojsk Lotniczych

\begin{abstract}
The development of unmanned aerial systems (UAS) encountered the problem of controlling the process of technical operation. The literature that is available to the authors lacks credible information concerning the principles of specifying the strategy and control of the process of UAS operation. Hence, it is necessary to recognise and interpret the basic UAS operation features. The purpose of the publication is to present the properties of the UAS as an object of operation and the mutual relation of the technical operation process with the UAS' technical condition alteration process. We present the results of analyses in terms of functionality and the UAS' utility potential. The publication pays special attention to the properties of the UAS as an object of operation. The paper includes the analysis of the UAS operation principles and the specification of the advantage and disadvantage of those principles, i.e. using a non-repairable UAS until damaged, using a repairable UAS until damaged, periodical technical servicing, continuous diagnostic operation. The proposals for the control models in the UAS operation system have also been included.
\end{abstract}

Keywords: unmanned aerial system, technical operation, servicing, technical condition, damage

Streszczenie: Wraz z rozwojem bezzałogowych systemów powietrznych (BSyP) pojawit sie problem sterowania procesem ich eksploatacji technicznej. $W$ dostepnej autorom literaturze brakuje wiarygodnych informacji dotyczacych zasad określania strategii isterowania procesem eksploatacji BSyP. W zwiazku z tym istnieje potrzeba rozpoznania oraz interpretacji podstawowych charakterystyk eksploatacyjnych BSyP. Celem publikacji jest przedstawienie własności BSyP, jako obiektu eksploatacji $i$ wzajemnego zwiazku procesu eksploatacji technicznej z procesem zmiany stanu technicznego BSyP. Przedstawiono wyniki analizy $w$ zakresie funkcjonalności i potencjału użytkowego BSyP. W publikacji szczególna uwage zwrócono na własności BSyP jako obiektu eksploatacji. Dokonano analizy możliwych zasad eksploatacji BSyP oraz omówiono zalety $i$ wady tych zasad tj.: użytkowania nienaprawialnego BSyP do uszkodzenia, użtkowania naprawialnego BSyP do uszkodzenia, obstugiwania technicznego okresowego, obstugiwania diagnostycznego ciagłego. Przedstawiono propozycję modeli sterowania w systemie eksploatacji BSyP.

Stowa kluczowe: bezzałogowy system powietrzny, eksploatacja techniczna, obstugiwanie, stan techniczny, uszkodzenie 
Controlling the operation process of the unmanned aerial system

Sterowanie procesem eksploatacji technicznej bezzałogowego systemu powietrznego

\section{CONTROLLING THE OPERATION PROCESS OF THE UNMANNED AERIAL SYSTEM}

\section{Introduction}

One of the most important tasks in the group of activities aimed at increasing the quality of unmanned aerial systems (UAS) is the increase of their operation's effectiveness. The UAS has specific features when comparing it to objects controlled or steered directly by a man (crew) and it is thus possible to presume that it will be subject to modified operation principles. It is necessary to recognise and interpret the basic UAS operation properties, including their functions and utility potential as well as the resulting operation properties.

The results of scientific research on the operation of manned aircraft (MA) are published in numerous technical and science magazines [1,2,4,5,7,10,11,12]. There is however very few information regarding the operation of UAS. The publications mainly present difficulties concerning the documentation by UAS manufacturers of their operation strategy. They indicate that UAS users must develop their own principles and procedures of controlling the process of their technical operation $[15,16]$. The literature analysis demonstrates that the operation of MA or UAS is a two-stage process. The first stage is their use and the second is servicing. Use is the process of executing tasks for which the UAS was intended. During use, the UAS become subjected to the impact of a wide spectrum of factors affecting their technical condition in various ways. The use is usually accompanied by UAS' degradation (i.e. wear and destruction, property degradation) $[4,5,7,10,11]$. The factors affecting the technical condition of the UAS can be divided into two groups: structural and manufacturing factors as well as operation factors.

The structural and manufacturing factors determine the UAS' initial quality and include the following:

- selection of structural solutions,

- selection of elements and materials,

- process of manufacturing of work pieces and assemblies, UAS assembly and testing,

- quality of manufacturing, regular and initial control features.

The operation factors determine the alteration of the technical condition of the

UAS and its assemblies during use and include the following:

- selection of correct ranges of the UAS' operation and its technical servicing,

- qualification and labour quality of the servicing personnel,

- operating conditions of the UAS assemblies (temperature ranges, physical and chemical properties of materials, impact of outside environment), 
- magnitude and periodicity of recurrence of operation loads transferred by the UAS assemblies.

The destruction results in the loss of the UAS' fitness for use. It is necessary to introduce an intervention aimed at recreating the required properties, i.e. recreation of the required technical condition $[4,5,11]$. Servicing is the process of recreating the necessary properties of the UAS, i.e. process of executing the servicing task. The desirable result of the servicing process is the UAS' fitness for use.

The quantitative features of the operation factors vary widely and their impact on the UAS' technical condition is random. The alteration of the parameters and features of UAS elements in time is the effect of on-going destructive processes taking place within them. In principle, these processes take place in time, and their internal mechanism and rate depend on the material structure and properties, stresses caused by loads, temperature and other factors. The destructive processes causing damage to the UAS' elements and systems are complex and their nature has not yet been sufficiently studied. The variety and stochastic nature of the impact of operation factors on the UAS result in the fact that they have a various actual technical condition despite having identical operation time or length of operation. As result, the operation time or calendar period of use does not clearly determine the UAS' technical condition and it is necessary to control its technical condition in the operation process.

The principles of controlling the UAS' technical operation must therefore be taken into account during their designing and construction, because it has particular impact on the technical condition and flight safety of unmanned aerial vehicles (UAV). The designer's/constructor's thinking in terms of operation should be an important element in the construction of UAS. Ensuring effective operation of the UAS, with a set composition and structure of the system, takes place mainly thanks to correct operation management and ultimately, in adopting proper operation control models.

\section{Unmanned aerial system as an operation object}

An unmanned aerial system (UAS) is a system based on unmanned aerial vehicles (UAV) and the system of steering and controlling their flight, take-off and recovery (fig. 1).

The main subsystem of the UAS is the unmanned aerial vehicle (UAV). The UAV is a structure consisting of the following elements (fig. 2): airframe (fuselage, wing with flaps and feathers, fins with planes, drive motor including its control and fuel supply systems, on-board control system (OCS), power supply, transmission system and task systems. 
Controlling the operation process of the unmanned aerial system

Sterowanie procesem eksploatacji technicznej bezzałogowego systemu powietrznego

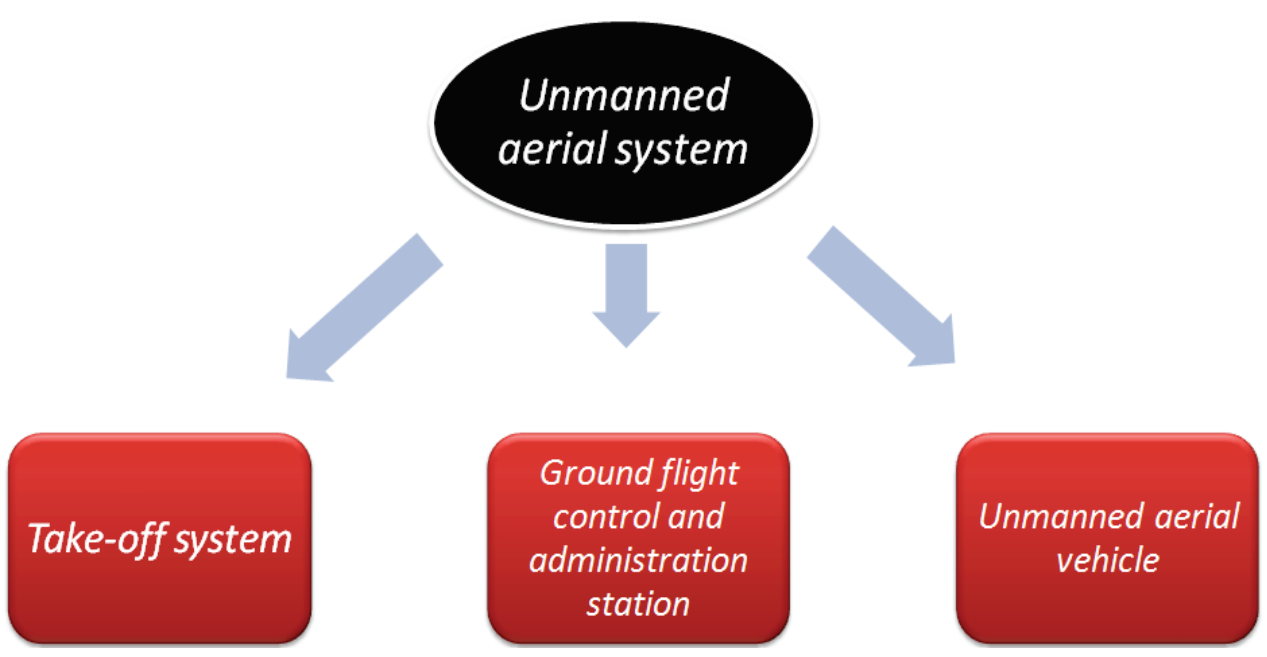

Fig. 1 Unmanned aerial system diagram

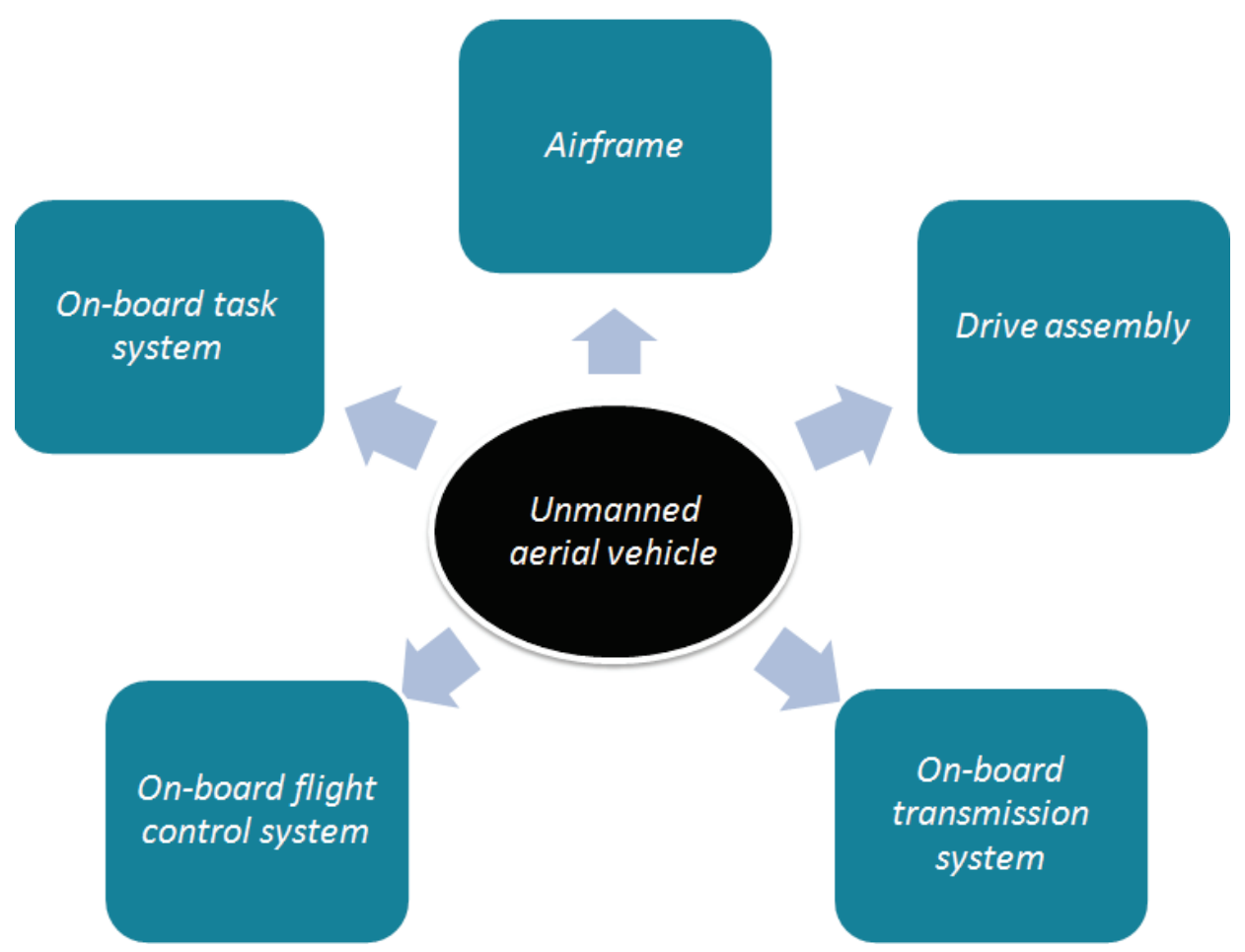

Fig. 2 Unmanned aerial vehicle diagram 
One of the most important UAS elements is the flight control system (FCS). The FCS includes the on-board control system (OCS) and the ground control system (GCS). The purpose of the FCS' OCS is the stabilisation of the UAV in flight and execution of the set flight route, reading of flight parameters (aerodynamic parameters from pressure sensors connected to the Pitot tube, spatial orientation from the accelerometers as well as speed and navigation gyroscopes from the GPS satellite navigation receiver), filtering and processing of the signals by the micro-computer system, preparation of the signal for transmission (via a radio-modem) and then sending the data to the ground flight control and administration station (GFCAS). The FCS' OCS consists of the on-board radiomodem, autopilot, control signals and power distribution system (CSPDS), flight control surfaces moving servomechanisms (flight control by slanting, tilting and deviation), drive unit control system, remote control instrument receiver as well as transmitter and receiver antennas. The main element of the FCS' OCS is the autopilot (fig. 3) with the following systems: spatial orientation, GPS navigation, mission supervision, automatic flight control via slanting, tilting and deviation, altitude and speed. Tasks executed by the autopilot include the following:

- real-time determination of the necessary angular velocities and accelerations,

- ensuring the UAV's stabilisation (in a feedback loop) to provide protection against quick interference, like air blasts, turbulence,

- real-time determination of the UAV's spatial orientation angles,

- real-time determination of the flight course, speed and altitude,

- acquisition of data on the UAV's position, target point location and data conversion,

- data link with the ground station to supervise the UAV's flight.

The ground flight control and administration station (GFCAS) constitutes an integral part of the OCS, which is necessary to operate the UAV. The task of the GFCAS is to control the UAV during task execution in real time, during various missions, reception of transmission sent from the vehicle and decoding the data, graphic presentation of the pilot and navigation parameters, presentation of the map providing the imaging of the current and planned flight route (fig. 4). The ground flight control and administration station includes a computer with the NSS software (UAV control without the operator's direct visual contact with the UAV automatic flight mode), imaging monitors, remote control instruments (control executed in the scope of the operator's visual contact with the UAV - manual control mode) and a radio-modem module including a transmitter and receiver antenna.

The take-off support system is another element of the UAS. Depending on the UAS type, it is possible to take-off on the system's own landing gear or using a pneumatic or line take-off launcher. 
Controlling the operation process of the unmanned aerial system

Sterowanie procesem eksploatacji technicznej bezzałogowego systemu powietrznego

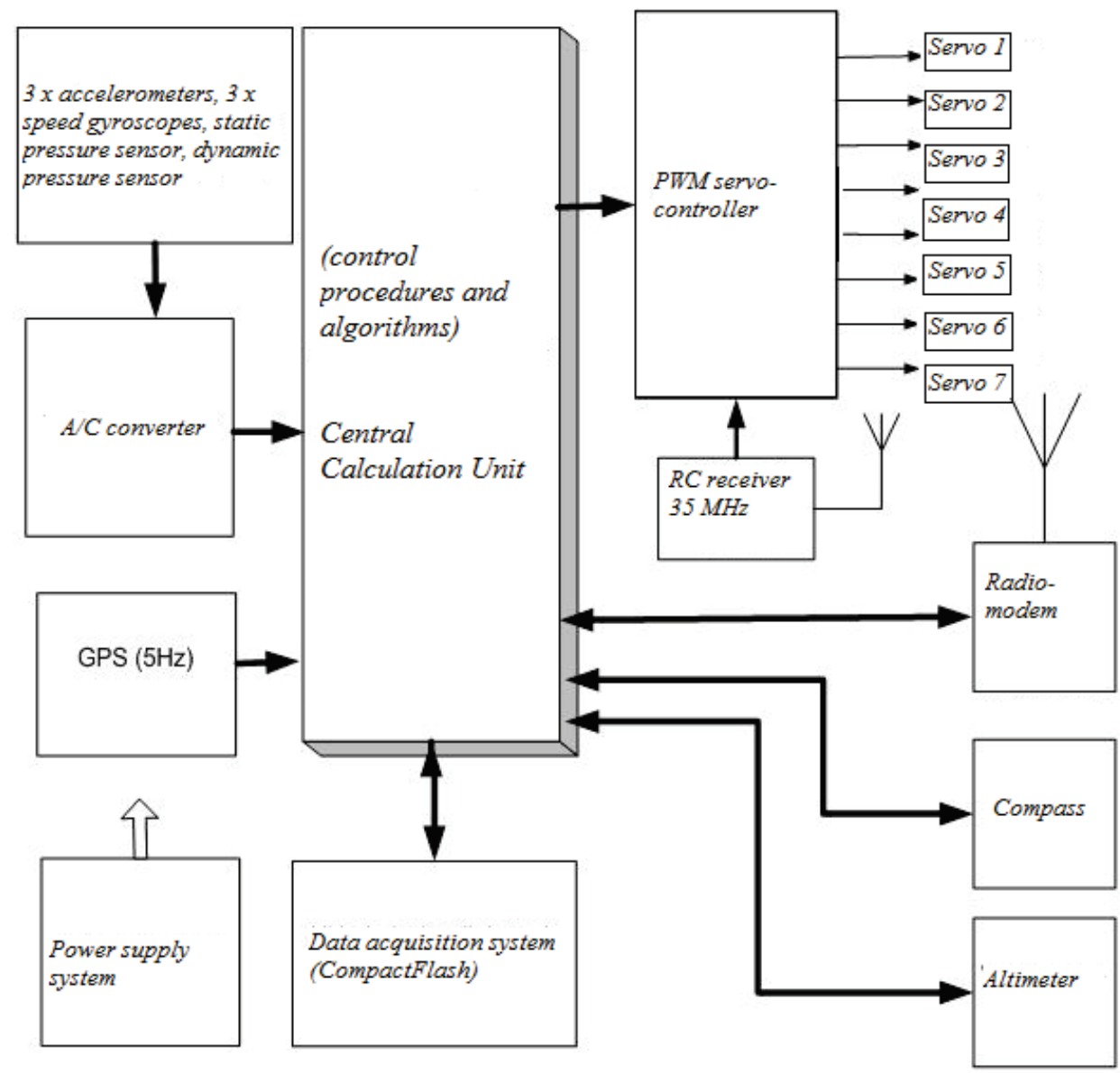

Fig. 3 General on-board control system autopilot modules diagram

a)

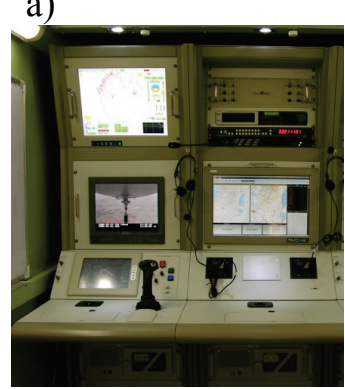

b)

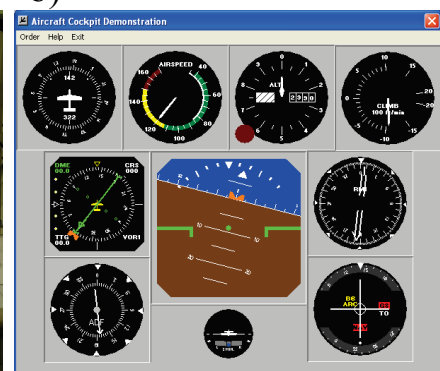

c)

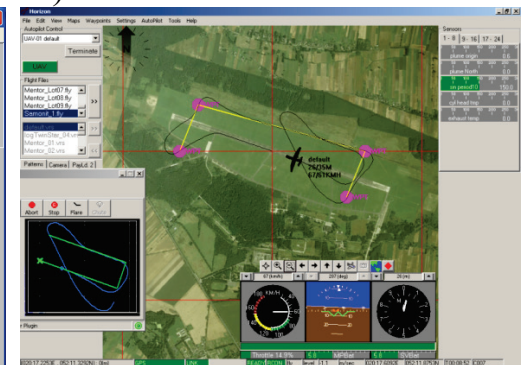

Fig. 4 UAS flight control and administration station:

a) overall view, b) graphic presentation of pilot and navigation parameters, c) current and planned flight route imaging map 


\section{Description of the process of technical operation of unmanned aerial systems}

The UAS' operation is characterised by the existence of an objective process of its technical condition alteration and a subjective process of its technical operation, the latter of which presents subsequent alterations in the operation state. It is especially important for the mutual relation between the two processes to be that in which the technical operation states are determined in complete accordance with the UAS' technical conditions. The operation states include: use as intended (flight), technical diagnostics, technical servicing, overhaul, readiness, waiting for transition into any of the specified conditions, etc.

The UAS' technical operation states occur in sequence and continuously, i.e. moments in time $t_{1}, t_{2}, \ldots$ become correlated and develop the process. In these moments of time the UAS makes transitions from one condition to the other. The quantitative characteristics of the transitions must include an examination not of the time of transition to the adjacent condition, but the relative value $p_{i k}$ of the UAS transition frequencies from condition $i$ to condition $k$, where $i, k$ belong to the set of conditions, i.e. $i, k \in\{r\}$. For this purpose, it is necessary to determine the number $n_{i}$ of the process' transition into condition $i$ in a sufficiently long section of technical operation observation time and calculate the number of direct transitions $n_{i k}$ from condition $i$ to condition $k$. The presented method can be used to calculate the frequency $p_{i k}=\frac{n_{i k}}{n}$ for each of the conditions $i \in\{r\}$ and compare the transition frequency matrix $\left\|p_{i k}\right\|=P$. The matrix will determine the UAS' local technical operation structure. In turn, the frequencies $\delta_{i}$ of the UAS transitions into the technical operation state $i$ in time $T_{o b s e r}$ will amount to $\delta_{i}=n_{i} \sum n_{k}$, where $N$ is the overall number of observed states in the interval $T_{o b s e r}$. By unsing the above dependency it is possible to develop a frequency table which will constitute an established condition frequency vector. The set of matrices $\left\|p_{i k}\right\|=P$ and the frequency vector $\delta$ is determined by the so called established chain of technical operation $[3,6,8,9,14]$. The UAS' technical operation can therefore be represented by using the theorem for semi-Markov processes, the formal description of which can be found in literature $[8,9,14]$.

Considering the above, the probable structure of the UAS' technical operation can be determined using the initial probability distribution and the single-step transition probability function, which describes the method of state transitions.

In addition to the single-step transition probabilities we will consider the probabilities $\mathrm{R}_{\mathrm{ij}}$ of transitioning from condition $i$ to condition $j$ in $\mathrm{n}>1$ steps. 
Controlling the operation process of the unmanned aerial system

Sterowanie procesem eksploatacji technicznej bezzałogowego systemu powietrznego

The distribution of transition probabilities from state $i$ to state $j$ can be presented as follows:

$$
R_{i j}=\sum_{k \neq j}^{N} p_{i k} R_{k j}+p_{i j} R_{i j}
$$

where $N$ is the overall number of the technical operation states.

Using the Gram-Schmidt ortogonalisation method, the distribution of transition probabilities between particular conditions can be presented in the form of a matrix $[9,14]$ :

$$
R=\left\|R_{i j}\right\|=P\left(R-R_{d q}\right)+P R_{d q},
$$

where $R_{d q}$ is the diagonal matrix obtained from $R$ by replacing non-diagonal elements with zeroes.

The established ergodic chain features a single vector of solution $\delta=\left(\delta_{1}, \delta_{2}, \ldots, \delta_{N}\right)$ that fulfils the requirement $\delta=\delta P$.

By indicating $R=R_{d q}+R_{0}$ we obtain [14]:

$$
R_{d q}=(P-M) R_{0}+P,
$$

where $\mathrm{M}$ is the identity matrix (1) with the dimension of $\mathrm{N} x \mathrm{~N}$.

By multiplying both sides of the dependency (3) by $\delta$ we will obtain $\delta R_{d q}=\delta P=\delta$. Therefore $R_{d q}=1$.

The distribution of transition probabilities from state $i$ to state $j$ can be finally presented as follows:

$$
R_{i j}=\sum_{k \neq j}^{N} p_{i k} R_{k j}+p_{i j} .
$$

The result is correct for chains established for finite processes with communicating states [14]. If the process does not feature any absorbing states and their general number is finite, it is possible to point out a route with a finite length in the given process. When following this route, the process may transition from one state to the other in a finite number of steps.

The average number of steps $m_{i j}$ to the first transition from state $i$ to state $j$ meets the renewal equation in the following form:

$$
m_{i j}=\sum_{k \neq j} p_{i k}\left(m_{k j}+1\right)+p_{i j}
$$


It is thus easy to demonstrate that the average number of steps $m_{i i}$ necessary for the process to transition into state $i$ is expressed with the following formula:

$$
m_{i i}=1 / \delta_{i} .
$$

The function of the distribution of the process' time of unconditional residing in state $i$ can be determined from the following dependency:

$$
F_{i}(t)=\sum_{j=1}^{N} p_{i j} F_{i j}(t) \text {. }
$$

If $\tau_{i k}$ is the average time corresponding to distribution $F_{i j}(t)$, then (6) can be used to determine the average time $\tau_{i}$ of the process' unconditional residing in state $i$, i.e.:

$$
\tau_{i}=\sum_{k=1}^{N} p_{i k} \tau_{i k} .
$$

Using the above deliberations, the distribution of the probability of the process' first transition to state $i$ to state $j$ can be presented in the form of the following matrix:

$$
L=\left\|L_{i j}\right\|=\left(L-L_{d q}\right)+D,
$$

where $\mathrm{D}$ is a matrix, the elements of which are average times $\tau_{i}$, whereas $L_{d q}$ is the diagonal matrix, obtained from $L$ by replacing non-diagonal elements with zeroes. The expression (8) can be presented as follows:

$$
L_{i j}=t_{i j} \sum_{k \neq j}^{N} p_{i k} t_{k j}+\tau_{i}
$$

Respectively for the average time of the process' recovery to state $i$ we will obtain the following:

$$
t_{i i}=\frac{1}{\delta_{i}} \sum_{k=1}^{N} \delta_{k} \tau_{k}
$$

The average time of UAS' operation in state $j$ of the technical operation process between two subsequent entries into state $i$ can be presented with the following formula: $\varphi_{j i}=\frac{\delta_{j}}{\delta_{i}} \tau_{j}$, where $\delta_{j} / \delta_{i}$ is the number of transitions into state $j$. This means that $t_{i i}=\sum_{j=1}^{N} \varphi_{j i}$.

The probability of transition from state $i$ to state $j$ in the time not exceeding the value $t$ will be as follows:

$$
p_{i j}(t)=p_{i j} F_{i j}(t)
$$


Controlling the operation process of the unmanned aerial system

Sterowanie procesem eksploatacji technicznej bezzałogowego systemu powietrznego

Using the Gram-Schmidt ortogonolisation method for finite processes with communicating states we can present the following:

$$
\lim p_{i j}(t)=\frac{\tau_{j}}{t_{j j}},
$$

for any $t_{i}<\infty$ and any functions $F_{i}(t)=\sum_{j=1}^{n} p_{i j}(t)$.

According to $[8,14]$ the expression (12) represents the coefficient of use in state $j$. If $j$ is the target state of the operation process, then $\tau_{j} / t_{j j}$ may be described as the target function of the technical operation process. The target function may be considered as the coefficient of use and its maximum value may be used as the criterion of optimisation of technical operation.

After determining $K_{j}=\tau_{j} / t_{j j}$ and using the expression (10) we can note the following:

$$
K_{j}=\frac{\tau_{j}}{\tau_{j}+\frac{1}{\delta_{j}} \sum_{k \neq j}^{N} \delta_{k} \tau_{k}} .
$$

Because $K_{j}>0$ for all finite sets of states developed by their expansion and $\sum_{j=1}^{N} K_{j}=1$ then $K_{j}$ is the cumulative distribution of the probability function $P_{j k}$. $K_{j}$ is also the function of the technical operation process and can thus be used as the target function. The maximum value $K_{j}$ can be adopted as one of the criteria of optimisation of the technical operation process.

\section{Control models in the operation of unmanned aerial systems}

The main elements of the UAS' operation system are presented in table 1.

\begin{tabular}{|c|c|c|c|}
\hline \multicolumn{4}{|c|}{ 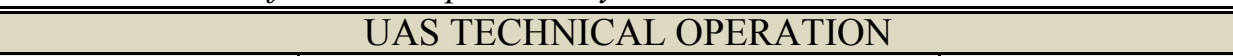 } \\
\hline \multirow[b]{2}{*}{ Operation system } & \multicolumn{2}{|c|}{ Operation process } & \multirow[b]{2}{*}{$\underline{\text { Operation }}$ management } \\
\hline & $\begin{array}{l}\text { Controlled } \\
\text { processes }\end{array}$ & $\begin{array}{c}\text { Uncontrolled } \\
\text { processes }\end{array}$ & \\
\hline Operation object & Use processes & \multirow{4}{*}{$\begin{array}{l}\text { damage potential } \\
\text { and degradation }\end{array}$} & $\begin{array}{l}\text { control models } \\
\text { in operation }\end{array}$ \\
\hline operation base & $\begin{array}{l}\text { Servicing } \\
\text { processes }\end{array}$ & & diagnostics \\
\hline operation staff & \multirow{2}{*}{$\begin{array}{c}\text { use and } \\
\text { operation logistics }\end{array}$} & & \multirow[b]{2}{*}{ operation testing } \\
\hline $\begin{array}{l}\text { operation } \\
\text { environment }\end{array}$ & & & \\
\hline
\end{tabular}

Tab. 1 Elements of the UAS operation system 
The control (administration) system in the operation of unmanned aerial systems can be executed according to the open (developed) (fig. 5) and closed (fig. 6) diagram.

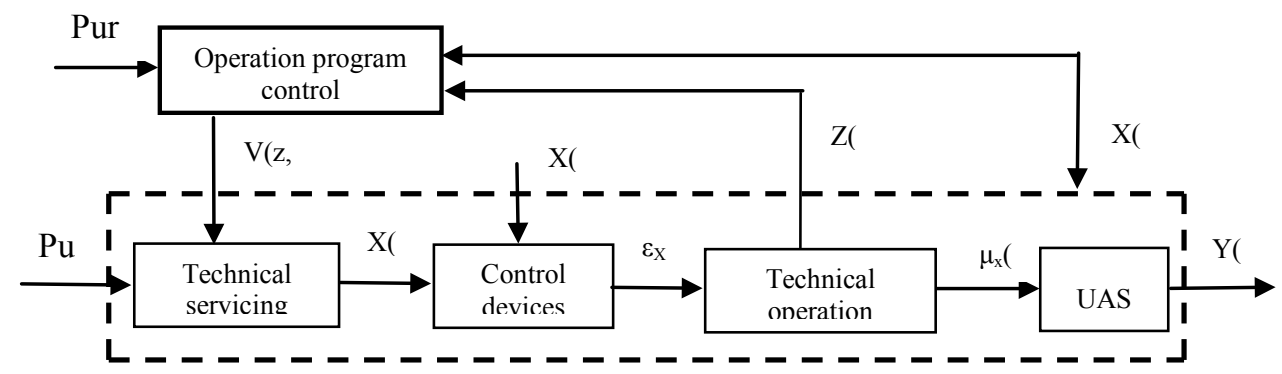

Fig. 5 Open (developed) control of the UAS' technical operation and technical condition

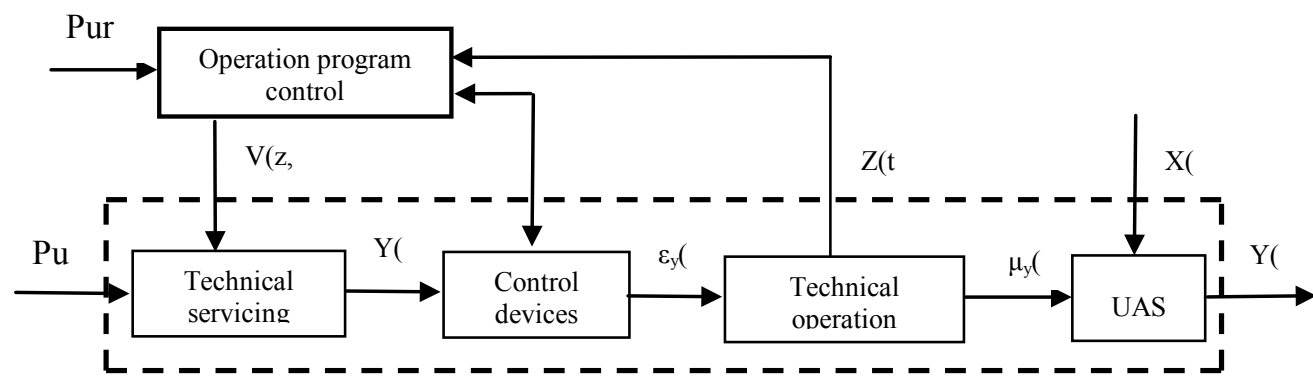

Fig. 6 Closed control of the UAS' technical operation and technical condition

The open control diagram executes the control (administration) principle via excitation (of the input parameter) $X(t)$ due to external factors. It can be used if the external excitation can be measured and its correlation with the input parameter $Y(t)$, which characterises the UAS' technical condition, can be determined. The open control (administration) diagram may include the traditional method of operation based on the execution of preventive works with planned intervals of the time of completed work $X(t)=t$.

The closed diagram executes the control (administration) principle via adjusted value deviations (of the input parameter) $Y(t)$. The adjusted value $Y(t)$ is compared to the set impact $\bar{Y}(t)$. The deviation $\varepsilon(t)$ is subject to determination, because it affects the corresponding control impacts $\varepsilon_{y}(t)$ on the technical operation, and thus on the adjustment impact $\mu_{y}(t)$ on the UAS, which reduces this deviation. As the adjusting value we can utilise the reliability indicators, e.g. damage flux parameter. It is accompanied by the determination of the correlation between the technical operation and the process of the technical condition alteration. 
Controlling the operation process of the unmanned aerial system

Sterowanie procesem eksploatacji technicznej bezzałogowego systemu powietrznego

The set control (administration) program utilises the diagram marked with dotted lines in fig. 5 and 6. The changes (corrections) are introduced to the control program via the program control unit. Depending on the measured values of the UAS' output parameters $Y(t)$ or $X(t)$ and technical operation indicators $Z(t)$, the unit develops the operator $V(z, x)$ or $V(z, y)$ which ensures the changes in the control algorithms.

When developing the proposals for control models in the UAS' operation the authors used the classical model, which consists of the controlled and controlling system [5, 13]. Thus, when decomposing the UAS' operation system, we can distinguish the following subsystems:

- UAS operation execution system, which in turn consists of the use system and servicing system (controlled system),

- UAS operation control system (controlling system).

- When considering the UAS' operation strategies, we can distinguish the following types of strategies:

- operation of a non-repairable UAS - using the UAS until it is damaged, after which the object is terminated (fig. 7),

- operation of a repairable UAS - in case of damage, the possible decisions include repairing or terminating the object (fig. 8),

- operation of the UAS with periodical technical servicing (acc. to the service life) the assumption of this strategy is a strictly determined period of use, measured, for example, by the number of the UAS' flight hours, after which the planned servicing program (fig. 9) is executed,

- operation of the UAS with continuous diagnostic servicing (acc. to the technical condition) - this strategy assumes continuous monitoring of the object's technical condition during its use and making the decisions regarding technical servicing depending on the diagnostic data (fig. 10).

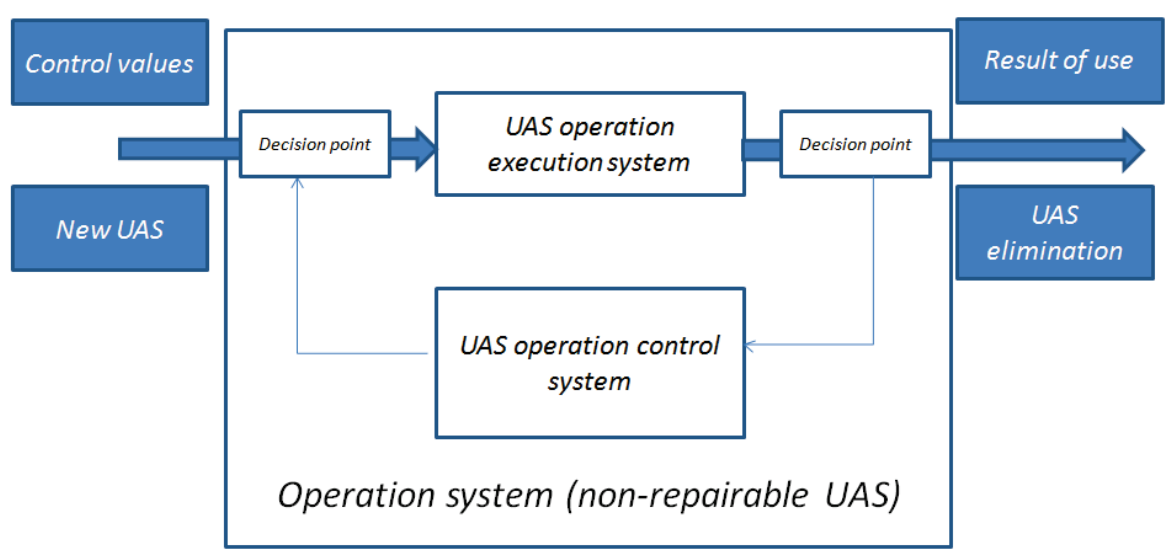

Fig. 7 Non-repairable unmanned aerial system operation model diagram 


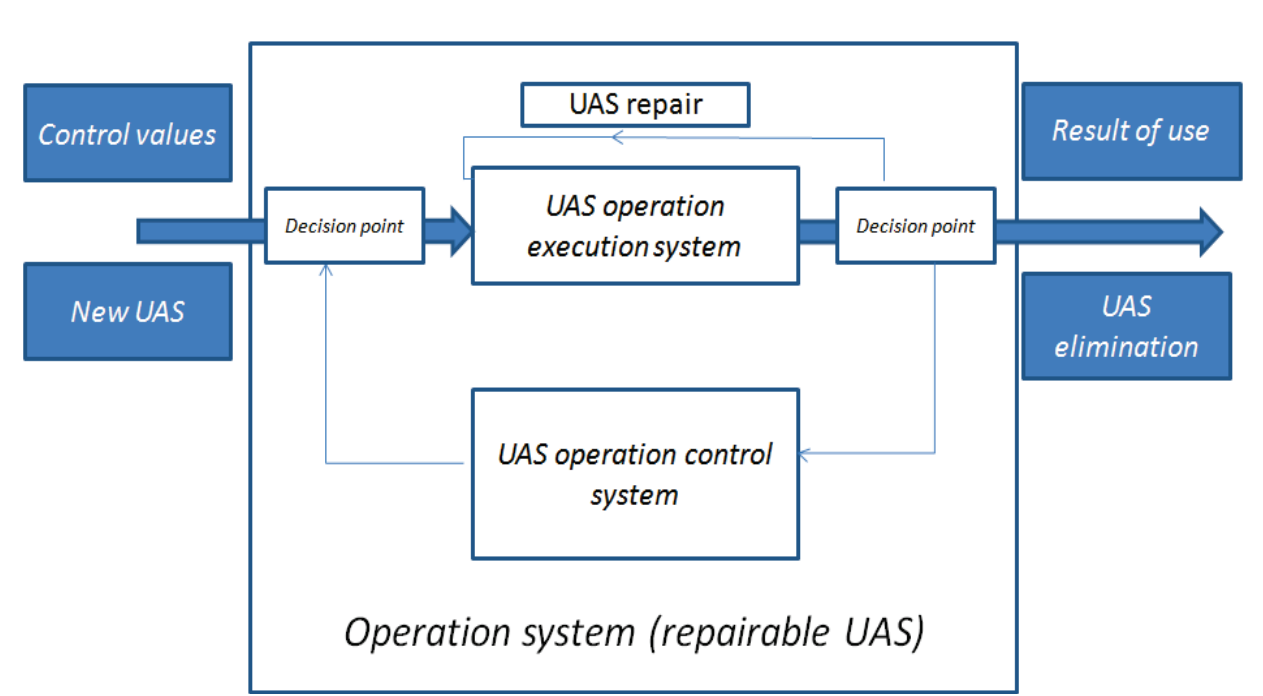

Fig. 8 Repairable unmanned aerial system operation model diagram

The adoption of strategies based on using the UAS until it is damaged (fig. 7 and 8) does not mean that no technical servicing is executed. The UAS elements undergo maintenance, adjustment or replacement, replenishment of the consumables. The characteristic feature of this approach is the lack of preventive action. This type of models may be applied to easily-replaceable models with a relatively low cost of purchase (e.g. aerial targets). It is however necessary to take into consideration the following disadvantages of this approach: risk related to the effects of damaging a UAS element, limited ability of planning the operation and random servicing nature.

Two further models of control in operation are based on the assumption that is it substantially more advantageous to take preventive action rather than eliminating the effects of damage. The operation strategy based on periodical technical servicing (fig. 9) is characterised by strictly planned servicing and rigorously observed periods of use. This type of operation system can be operated correctly if it is provided with information concerning the use standards and servicing resulting from the knowledge and experience of its design engineers. The plans concerning the technical servicing are developed based on operation studies and are not dependent upon the actual technical condition of the object. This type of model is characterised by the object operation control ease, but its disadvantage are the relatively high costs. 
Controlling the operation process of the unmanned aerial system Sterowanie procesem eksploatacji technicznej bezzałogowego systemu powietrznego

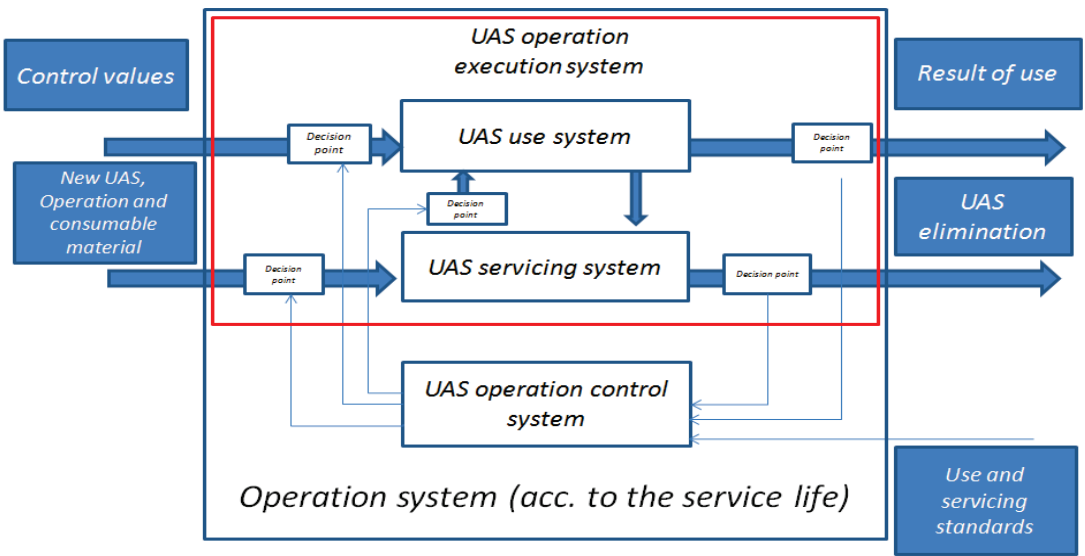

Fig. 9. Unmanned aerial system operation model with periodical technical servicing diagram

The last of the discussed operation strategies (with continuous diagnostic servicing) is characterised by making the decisions regarding technical servicing based on the on-going assessment of the unmanned aerial system's technical condition (fig. 10). The development capabilities of this type of operation approach have emerged along with the development of the diagnostic methods and IT systems, which are used to acquire, collect and analyse the data deriving from the UAS. It is necessary to note that the unmanned aerial system exploited according to this model should be characterised by very high servicing susceptibility and the servicing personnel should be qualified and experienced. The model enables very intensive UAS operation, however it involves a substantial increase in the costs related mainly to the expansion of IT systems.

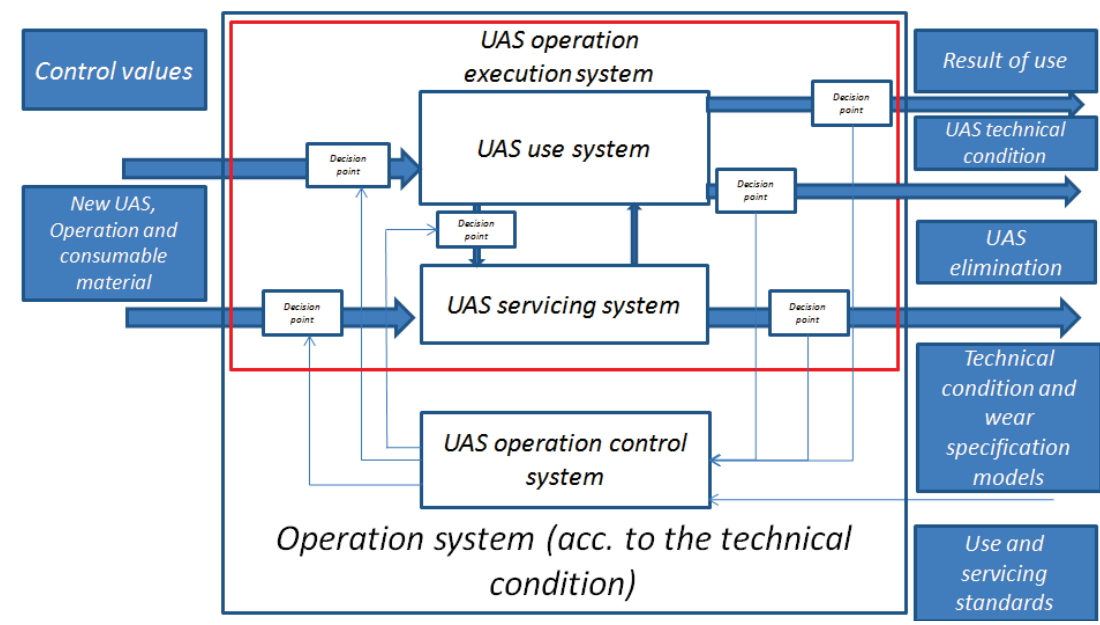

Fig. 10. Unmanned aerial system operation model with continuous diagnostic servicing diagram 


\section{Summary}

Considering the complex mutual impact of a large number of elements of an unmanned aerial system in the process of operation and it being affected by a wide spectrum of random factors, the effectiveness of operation is characterised by a substantial number of various indicators. Due to the fact that the operation of an unmanned aerial system includes conditions of its intended use, these conditions can be utilised to determine certain target functions including extremes in the form of a criterion for the process control strategy's optimisation. It was the reason for the search for the minimum number of indicators for the unmanned aerial system's operation, which would allow assessing the effectiveness with sufficient practical reliability. The set of operation states was divided into the subset of control aim states, i.e. state of use as intended (flight). It was proposed to use the target function for assessing the control (administration) quality, the extreme value of which may be used as the strategy's optimisation criterion.

Furthermore, it is worth noting that the making of operation decisions depends not only on the UAS' technical condition, but also on the properties of the surroundings (environment, cooperative and counteractive systems, etc.). The high variety of UAV's constituting a UAS makes it groundless to adopt a single, universal model of controlling the operation of all UAS types. In addition, the authors' previous experiences demonstrate that a single UAS type may include the adoption of various operation strategies for each of the system's elements.

Correct operation control can be achieved if the decision-maker receives both the information about the general laws that apply to the discussed system and on its current and future individual properties.

\section{Bibliography}

[1] Bloom Neil B. Reliability Centered Maintenance (RCM). Implementation made simple. McGraw- Hill, 2005.

[2] Bengtsson M., Olsson E., Funk P, Jackson M. Technical Design of Condition Based Maintenance System. Maintenance and Reliability Conference 2004.

[3] Czaplicki J. M. Terotechnology vs. Exploatation Theory. Scientific Problems of Machines Operation and Maintenance, nr 2 (154), 2008.

[4] Danielecki S. Eksploatacja samolotów [Aircraft operation]. Oficyna Wydawnicza Politechniki Wrocławskiej, Wrocław 2004. 
Controlling the operation process of the unmanned aerial system

Sterowanie procesem eksploatacji technicznej bezzałogowego systemu powietrznego

[5] Dawnarowicz O. Teoretyczne podstawy eksploatacji obiektów technicznych [Theoretical bases for technical object operation]. Zeszyty naukowe Politechniki Gdańskiej. Gdańsk 1993.

[6] Domańska J., Domański A., Augustyn D.R., Klamka J. A RED modified weighted moving average for soft real-time application. International Journal of Applied Mathematics and Computer Science, Vol. 24 (3), pp. 697-707, 2014.

[7] Gasiński L. Problemy jakości w eksploatacji maszyn i urzadzeń [Quality issues in exploiting machinery and devices]. Problemy Eksploatacji, Z.4, 1997.

[8] Grabski F., Jaźwiński J. Funkcje o losowych argumentach w zagadnieniach niezawodności, bezpieczeństwa i logistyki [Functions with random arguments in notions of reliability, safety and logistics]. Wydawnictwa Komunikacji i Łączności, Warszawa 2009.

[9] Jurlewicz T., Skoczylas Z. Algebra liniowa 2: definicje, twierdzenia, wzory [Linear algebra 2: definitions, theorems, formulae]. Oficyna Wydawnicza GiS, Wrocław 2005.

[10] Landowski B., Woropay M. Symulacja procesu eksploatacji obiektów technicznych poddanych obstudze profilaktycznej [Simulation of the operation of technical objects subjected to preventive servicing]. XXXI Szkoła Niezawodności, Szczyrk 2003.

[11] Legutko S. Eksploatacja maszyn [Machinery operation]. Wydawnictwo Politechniki Poznańskiej, Poznań 2007.

[12] Lewitowicz J. Podstawy eksploatacji statków powietrznych. Tom 3. Systemy eksploatacji statków powietrznych [Basics of aircraft operation. Volume 3. Aircraft operation systems]. Wydawnictwo Instytutu Technicznego Wojsk Lotniczych, Warszawa 2006.

[13] Niziński S., Żółtowski B. Zarządzanie eksploatacja obiektów technicznych [Technical facilities operation management]. Wydawnictwo MARKAR, Zielonka 2002.

[14] Pursell L., Trimble S. Y. Gram-Schmidt Orthogonalization by Gauss Elimination. The American Mathematical Monthly. Vol. 98 (6), pp. 544-549, 2017.

[15] http://www.faa.gov/about/initiatives/maintenance_hf/library/documents/media /human_factors_maintenance/maint_uav_nasa.pdf.

[16] http://hsi.arc.nasa.gov/publications/UAV_interimreport_Hobbs_Herwitz.pdf. 


\section{STEROWANIE PROCESEM EKSPLOATACJI TECHNICZNEJ BEZZALOGOWEGO SYSTEMU POWIETRZNEGO}

\section{Wstęp}

Jednym z ważniejszych zadań w kompleksie działań na rzecz podnoszenia jakości bezzałogowych systemów powietrznych (BSyP) jest zwiększanie efektywności ich eksploatacji. BSyP odznacza się specyficznymi cechami w porównaniu do obiektów sterowanych lub kierowanych bezpośrednio przez człowieka (załogę) i w związku z tym można domniemywać, że podlegał będzie zmodyfikowanym zasadom eksploatacji. Istnieje więc potrzeba rozpoznania oraz interpretacji podstawowych własności eksploatacyjnych BSyP, w tym ich funkcjonalności i potencjału użytkowego oraz wynikających stąd własności eksploatacyjnych.

Wyniki badań naukowych o eksploatacji załogowych statków powietrznych (SP) są publikowane w licznych czasopismach naukowo-technicznych $[1,2,4,5,7,10,11,12]$. Natomiast informacji dotyczących eksploatacji BSyP jest bardzo mało. Publikacje przedstawiają głównie trudności związane z udokumentowaniem przez producentów BSYP strategii ich eksploatacji. Wskazują one, że użytkownicy BSyP muszą sami opracowywać własne zasady i procedury sterowania procesem ich eksploatacji technicznej $[15,16]$. Z analizy literaturowej wynika, że eksploatowanie SP lub BSyP jest procesem zawierającym dwie fazy. Pierwsza faza to ich użytkowanie, a druga obsługiwanie. Użytkowanie jest to proces realizacji zadań do wykonania którego BSyP został przewidziany. $\mathrm{W}$ procesie użytkowania BSyP poddawane są oddziaływaniom szerokiego widma czynników wpływających w różny sposób na ich stan techniczny. Procesowi użytkowania towarzyszy zazwyczaj proces degeneracji BSyP (tzn. procesy ich zużywania i destrukcji, pogarszania ich właściwości) [4,5,7,10,11]. Czynniki wpływające na stan techniczny BSyP można podzielić na dwie grupy: konstrukcyjno-produkcyjne i eksploatacyjne.

Czynniki konstrukcyjno-produkcyjne określają początkową jakość BSyP i należą do nich:

- wybór rozwiązań konstrukcyjnych,

- wybór elementów i materiałów,

- technologia wytwarzania detali i zespołów, montaż i próby BSyP,

- jakość produkcji, charakterystyki kontroli bieżącej i wyjściowej.

Czynniki eksploatacyjne określają zmiany stanu technicznego BSyP i jego zespołów w procesie użytkowania i należą do nich:

- wybór prawidłowych zakresów eksploatacji BSyP i jego obsługi technicznej,

- kwalifikacje personelu obsługującego i jakość jego pracy,

- warunki pracy zespołów BSyP (zakresy temperaturowe, właściwości fizykochemiczne materiałów, oddziaływanie środowiska zewnętrznego), 
Controlling the operation process of the unmanned aerial system

Sterowanie procesem eksploatacji technicznej bezzałogowego systemu powietrznego

- wielkości i okresowość powtarzania się obciążeń eksploatacyjnych przenoszonych przez zespoły BSyP.

W rezultacie procesu destrukcji następuje utrata zdatności użytkowej BSyP. Konieczna jest interwencja ukierunkowana na odtworzenie wymaganych ich właściwości czyli odtworzenie wymaganego stanu technicznego [4,5,11]. Obsługiwanie jest to proces odtwarzania potrzebnych właściwości BSyP, czyli jest to proces realizacji zadania obsługowego. Pożądanym wynikiem procesu obsługiwania jest stan zdatności użytkowej BSyP.

Ilościowe charakterystyki czynników eksploatacyjnych zmieniają się w szerokim zakresie i ich wpływ na stan techniczny BSyP ma charakter losowy. Zmiana parametrów i charakterystyk elementów BSyP w czasie jest skutkiem zachodzących w nich procesów destrukcyjnych. Procesy te, z reguły przebiegają w czasie, a ich mechanizm wewnętrzny i prędkość zależą od struktury i właściwości materiału, naprężeń wywoływanych przez obciążenia, temperatury i od innych czynników. Procesy destrukcyjne powodujące uszkodzenia elementów i systemów BSyP są bardzo złożone $\mathrm{i}$ ich natura do tej pory jest zbadana niedostatecznie. Różnorodność i stochastyczny charakter oddziaływań czynników eksploatacyjnych na BSyP doprowadza do tego, że przy jednakowym czasie pracy lub długotrwałości ich eksploatacji mogą mieć one rozmaity rzeczywisty stan techniczny. W związku z tym czas pracy lub kalendarzowy okres użytkowania nie charakteryzują jednoznacznie stanu technicznego BSyP i pojawia się konieczność kontrolowania jego stanu technicznego w procesie eksploatacji.

Zasady sterowania procesem eksploatacji technicznej BSyP muszą być więc uwzględniane już na etapie ich projektowania i konstruowania, gdyż ma to szczególny wpływ na stan techniczny i bezpieczeństwo lotów bezzałogowych statków powietrznych (BSP). Myślenie eksploatacyjne projektanta-konstruktora powinno być istotnym elementem $\mathrm{w}$ budowie BSyP. Zapewnienie efektywnej eksploatacji BSyP, przy zadanym składzie i strukturze systemu, następuje przede wszystkim dzięki właściwemu zarządzaniu tą eksploatacją i w konsekwencji przyjęciu odpowiednich modeli jej sterowania.

\section{Bezzałogowy system powietrzny jako obiektu eksploatacji}

Bezzałogowy system powietrzny (ang. unmanned aerial system - UAS), jest to system oparty o bezzałogowe statki powietrzne (ang. Unmanned Aerial Vehicle $U A V)$ oraz system sterowania i kierowania ich lotem, startu i odzyskiwania (rys. 1).

Głównym podsystemem BSyP jest więc bezzałogowy statek powietrzny (BSP). BSP jest konstrukcją składającą się z następujących elementów (rys. 2): płatowca (kadłub, skrzydła z klapami i lotkami, stateczniki ze sterami, silnika napędowego wraz $\mathrm{z}$ układem jego sterowania i zasilania paliwem, pokładowego systemu sterowania (PSS), zasilania elektrycznego, systemu transmisji i systemów zadaniowych. 


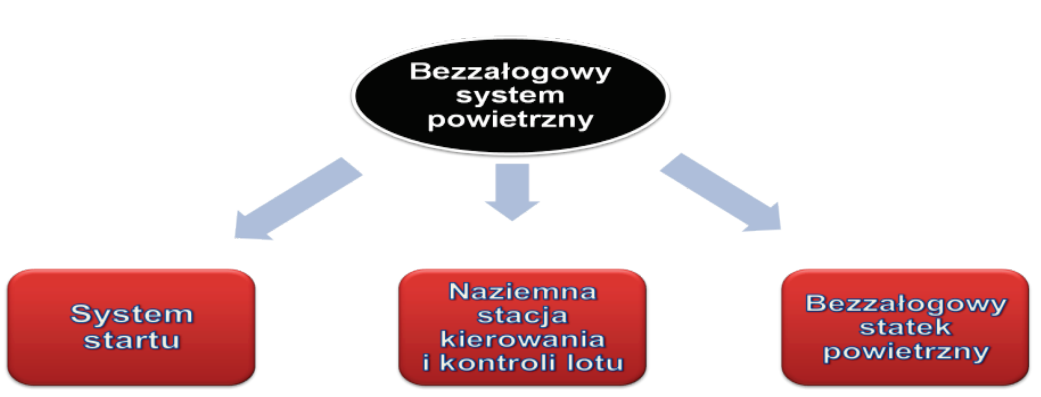

Rys. 1 Schemat bezzatogowego systemu powietrznego

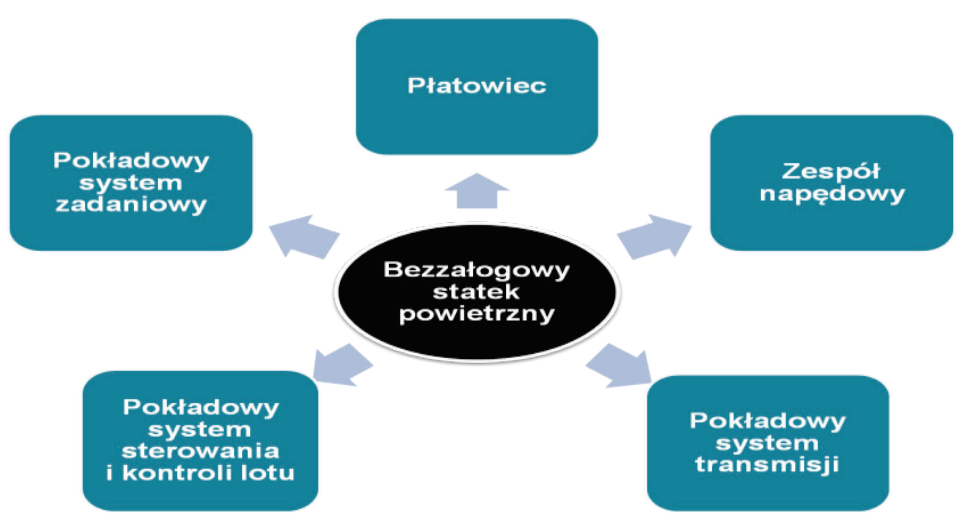

Rys. 2 Schemat bezzalogowego statku powietrznego

Jednym z najważniejszych elementów BSyP jest układ sterowania i kontroli lotem (USiKL). W skład USiKL wchodzą: pokładowy system sterownia (PSS) i naziemny system sterownia (NSS). Zadaniem PSS USiKL jest stabilizacja BSP w locie i realizacja zadanej trasy lotu, odczyt parametrów lotu (aerodynamicznych z czujników ciśnieniowych podłączonych do rurki Pitot'a, orientacji przestrzennej z przyspieszeniomierzy i żyroskopów prędkościowych oraz nawigacyjnych z odbiornika nawigacji satelitarnej GPS), odfiltrowanie i przetwarzanie tych sygnałów przez układ mikrokomputera, przygotowanie sygnału do transmisji (przez radiomodem), a następnie wysłanie danych do naziemnej stacji kierowania i kontroli lotu (NSKL). W skład PSS USiKL wchodzą: radiomodem pokładowy, autopilot, układ dystrybucji zasilania i sygnałów sterowania (UDZiSS), serwomechanizmy wychylania powierzchni sterowych (sterowania lotem w kanale pochylenia, przechylenia i odchylenia), układu sterowania zespołem napędowym, odbiornika aparatury zdalnego sterowania, oraz anteny nadawczo-odbiorcze. Głównym elementem PSS USiKL jest autopilot (rys. 3) z układami: orientacji przestrzennej, nawigacji GPS, nadzoru misji, automatycznego sterowania lotem w kanale pochylenia, przechylenia, odchylenia, wysokości i prędkości. 
Controlling the operation process of the unmanned aerial system Sterowanie procesem eksploatacji technicznej bezzałogowego systemu powietrznego

Zadania realizowane przez autopilota to:

- wyznaczanie w czasie rzeczywistym niezbędnych przyspieszeń i prędkości kątowych,

- zapewnienie stabilizacji BSP (w pętli sprzężenia zwrotnego) chroniąc przed szybkimi zakłóceniami typu podmuch, turbulencja,

- wyznaczanie w czasie rzeczywistym kątów orientacji przestrzennej BSP,

- wyznaczanie w czasie rzeczywistym kursu, prędkości i wysokości lotu,

- akwizycja danych o położeniu BSP, położeniu punktu docelowego oraz przeliczanie tych danych,

- utrzymywanie łączności (,data link”) ze stacją naziemną, w celu nadzorowania lotem BSP.

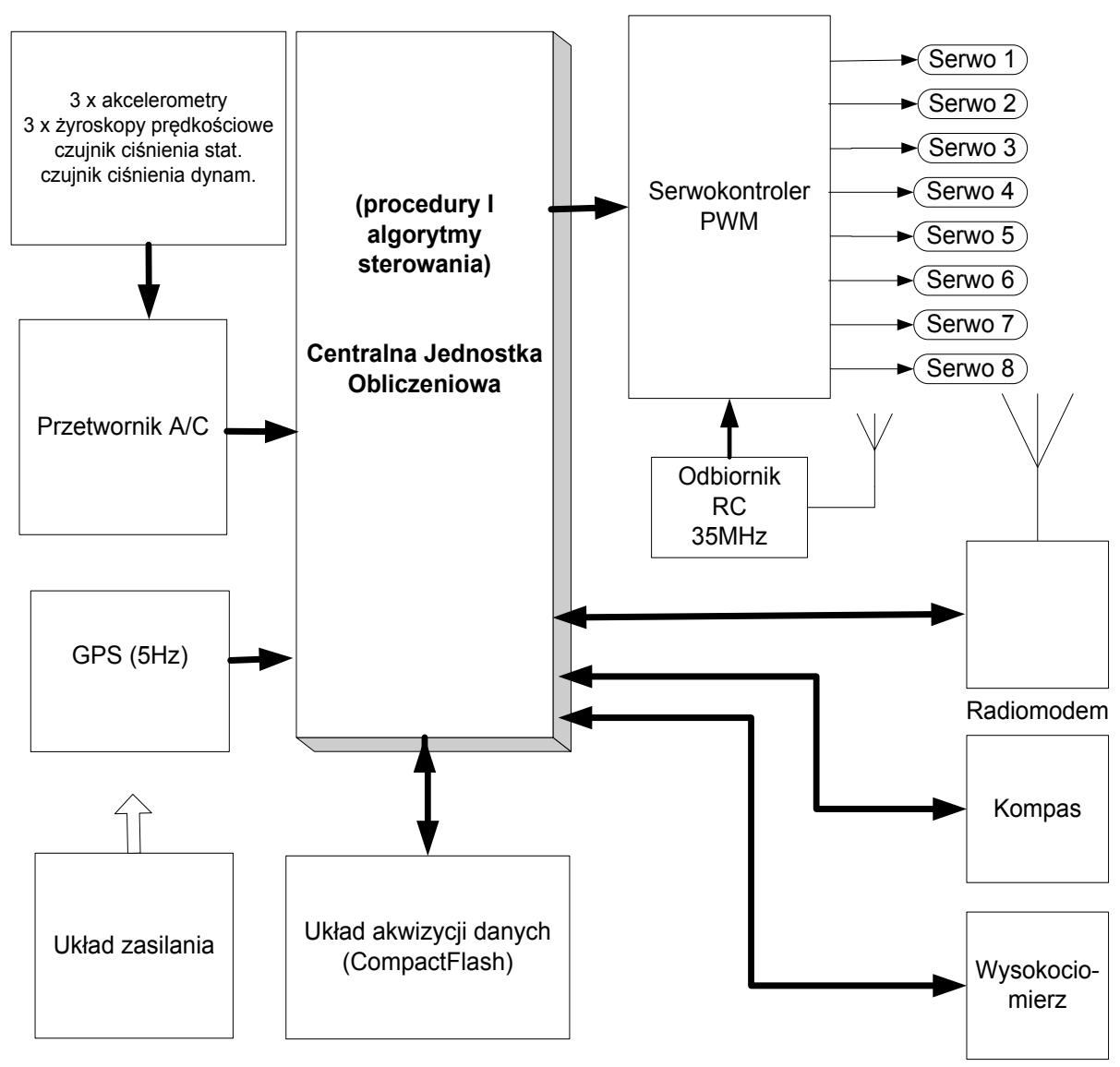

Rys. 3 Schemat ogólny modułów autopilota pokładowego systemu sterownia USiKL 
Naziemna stacja kierowania i kontroli lotu (NSKL) stanowi integralną cześć USiKL, która jest niezbędna do operowania BSP. Zadaniem NSKL jest: sterowanie BSP $\mathrm{w}$ czasie wykonywania zadania $\mathrm{w}$ rożnych misjach $\mathrm{w}$ czasie rzeczywistym, odbiór transmisji przesyłanej z pokładu i rozkodowywanie tych danych, prezentacja graficzna parametrów pilotażowo-nawigacyjnych, prezentacja mapy zobrazowującej planowaną i aktualnie realizowaną trasę lotu (rys. 4). W skład naziemnej stacji kierowania i kontroli lotu wchodzą: komputer z oprogramowaniem NSS (sterowanie BSP bez bezpośredniego kontaktu wzrokowego operatora z BSP - tryb lotu automatycznego), monitory zobrazowania, aparatura zdalnego sterowania (sterowanie realizowane w zakresie kontaktu wzrokowego operatora z BSP - tryb sterownia ręcznego) oraz moduł radiomodemu wraz z anteną nadawczo-odbiorczą.

a)

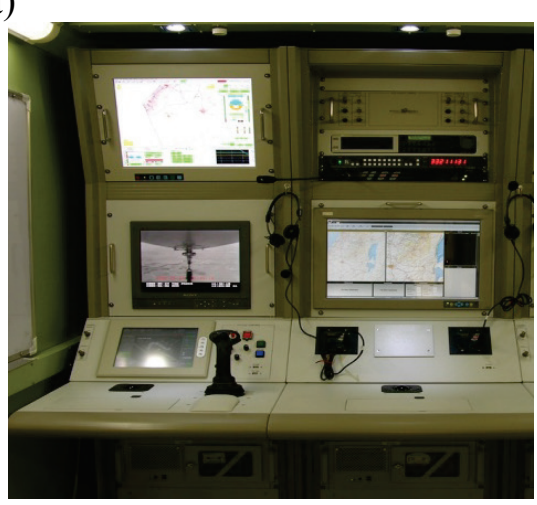

c) b)
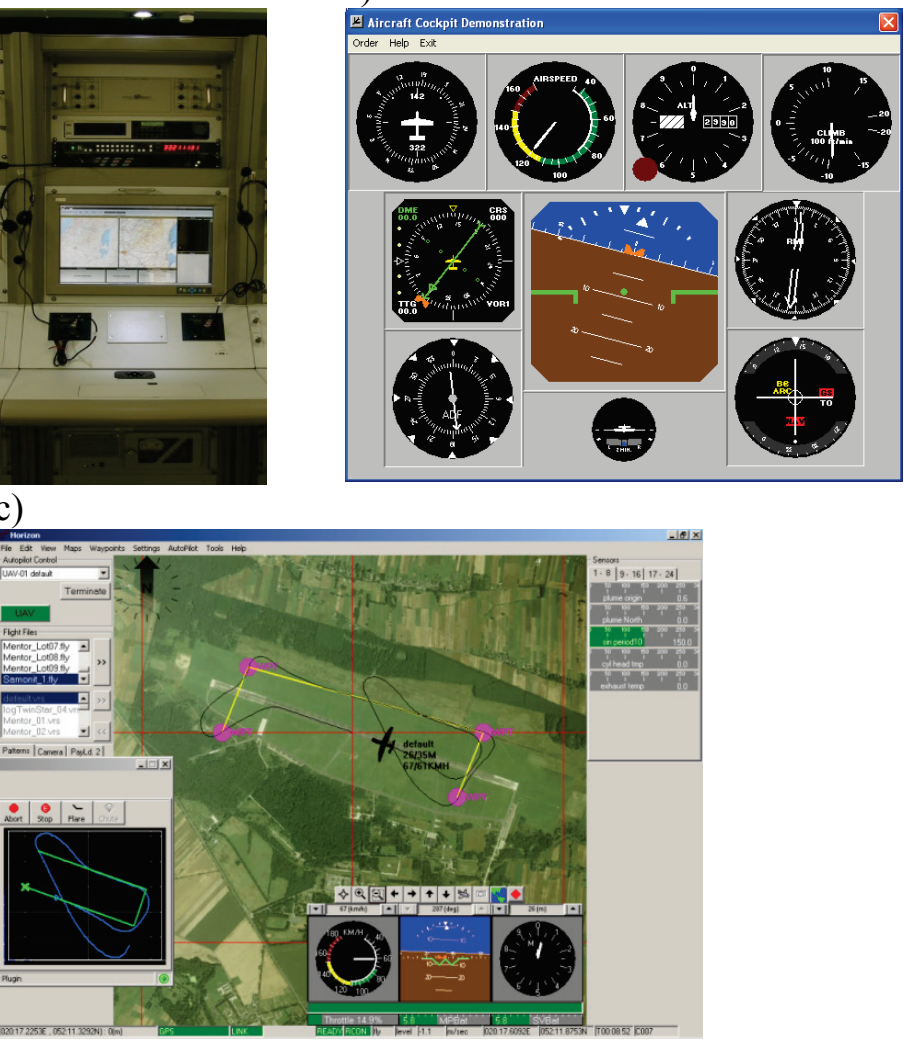

Rys. 4 Stanowisko kierowania i kontroli lotu BSYP: a) widok ogólny,

b) prezentacja graficzna parametrów pilotażowo-nawigacyjnych, c) mapa zobrazowania planowanej i realizowanej trasy lotu

Kolejnym elementem BSyP jest system wspomagania startu. W zależności od typu BSP możemy mieć do czynienia ze startem na własnym podwoziu lub jego wystrzeliwaniem z wyrzutni startowej pneumatyczne lub linowe. 
Controlling the operation process of the unmanned aerial system

Sterowanie procesem eksploatacji technicznej bezzałogowego systemu powietrznego

\section{Opis procesu eksploatacji technicznej bezzałogowych systemów powietrznych}

Eksploatacja BSyP charakteryzuje się istnieniem obiektywnego procesu zmiany jego stanu technicznego i subiektywnego procesu jego eksploatacji technicznej, z których ostatni przedstawia sobą następującą kolejno po sobie w czasie zmianę stanów eksploatacyjnych. Szczególnie istotny jest taki wzajemny związek miedzy tymi dwoma procesami, przy którym stany procesu eksploatacji technicznej wyznaczane są $\mathrm{w}$ pewnej zgodności $\mathrm{z}$ występującymi w BSyP stanami technicznymi. Do stanów eksploatacyjnych należą: wykorzystanie zgodne z przeznaczeniem (lot), diagnozowanie techniczne, obsługiwanie techniczne, remont, gotowość, oczekiwanie na przejście do każdego z wymienionych stanów itp. Stany procesu eksploatacji technicznej BSyP powstają w rozpatrywanym procesie kolejno i ciągle tj. momenty czasu $t_{1}, t_{2}, \ldots$ wiążą się $i$ tworzą proces. $W$ tych momentach czasu BSyP wykonuje przejścia $\mathrm{z}$ jednego stanu do drugiego. W charakterze charakterystyki ilościowej przejść należy rozpatrywać nie czas przejścia do stanu sąsiedniego a względne częstości $p_{i k}$ przejść BSyP z $i$-go stanu do stanu $k$-go, gdzie $i, k$ należą do zbioru stanów tj. $i, k \in\{r\}$. W tym celu na wystarczająco dużym ustalonym odcinku czasu obserwacji procesu eksploatacji technicznej należy określić liczbę $n_{i}$ trafiania procesu do $i$-go stanu i obliczyć liczbę bezpośrednich przejść $n_{i k}$ ze stanu $i$-go do stanu $k$-go. Przedstawionym sposobem można obliczyć częstości $p_{i k}=\frac{n_{i k}}{n_{i}}$ dla każdego ze stanów $i \in\{r\}$ i zestawić macierz częstości przejść $\left\|p_{i k}\right\|=P$. Macierz taka będzie określać strukturę lokalnego procesu eksploatacji technicznej BSyP. Z kolei częstości $\delta_{i}$ trafiania BSyP do $i$-go stanu procesu eksploatacji technicznej w czasie $T_{\text {obser }}$ będzie $\delta_{i}=n_{i} / \sum_{k=1}^{N} n_{k}$, gdzie $N$ jest ogólną liczba stanów obserwowanych w przedziale $T_{o b s e r}$. Wykorzystując powyższą zależność można sporządzić tablicę częstości, która będzie ulokowanym wektorem częstości stanów. Zbiór macierzy $\left\|p_{i k}\right\|=P$ i wektora częstości $\delta$ określa tak zwany łańcuch ulokowany (włożony) procesu eksploatacji technicznej $[3,6,8,9,14]$. Proces eksploatacji technicznej BSyP można więc opisać $\mathrm{z}$ pomocą teorii procesów semi-Markowa, którego opis formalny znajduje się w literaturze $[8,9,14]$.

Biorąc pod uwagę powyższe, struktura probabilistyczna procesu eksploatacji technicznej BSyP może być określona przy pomocy początkowego rozkładu prawdopodobieństwa i funkcji prawdopodobieństwa przejścia $\mathrm{w}$ jednym kroku opisującej w jaki sposób odbywają się zmiany stanów.

Jako uzupełnienie jednokrokowych prawdopodobieństw przejściowych rozpatrzymy prawdopodobieństwa $\mathrm{R}_{\mathrm{ij}}$ przejścia $\mathrm{z} i$-go stanu do stanu $j$-go $\mathrm{w} \mathrm{n}>1$ kroków. 
Rozkład prawdopodobieństw przejść $\mathrm{z} i$-go stanu do stanu $j$-go może być przedstawiony jako:

$$
R_{i j}=\sum_{k \neq j}^{N} p_{i k} R_{k j}+p_{i j} R_{i j}
$$

gdzie $N$ jest ogólną liczbą stanów procesu eksploatacji technicznej.

Wykorzystując metodę ortogonalizacji Grama-Schmidta, rozkład prawdopodobieństw przejść między poszczególnymi stanami może być przedstawiony w postaci macierzy $[9,14]$ :

$$
R=\left\|R_{i j}\right\|=P\left(R-R_{d q}\right)+P R_{d q},
$$

gdzie $R_{d q}$ jest macierzą diagonalną otrzymaną z $R$ przez zamianę elementów nie diagonalnych zerami.

Dla ergodycznego łańcucha ulokowanego istnieje pojedynczy wektor rozwiązania $\delta=\left(\delta_{1}, \delta_{2}, \ldots, \delta_{N}\right) \quad$ spełniający warunek $\delta=\delta P$.

Oznaczając $R=R_{d q}+R_{0}$ otrzymujemy [14]:

$$
R_{d q}=(P-M) R_{0}+P,
$$

gdzie $\mathrm{M}$ jest tożsamościową (jedynkową) macierzą o wymiarze $\mathrm{N} \times \mathrm{N}$.

Mnożąc obie strony zależności (3) przez $\delta$ otrzymamy $\delta R_{d q}=\delta P=\delta$. A zatem $R_{d q}=1$.

Rozkład prawdopodobieństw przejść z $i$-go stanu do stanu j-go można ostatecznie zapisać:

$$
R_{i j}=\sum_{k \neq j}^{N} p_{i k} R_{k j}+p_{i j} .
$$

Wynik ten jest słuszny dla łańcuchów ulokowanych dla skończonych procesów ze stanami komunikującymi się [14]. Jeżeli proces nie ma stanów pochłaniających i ogólna ich liczba jest skończona, to $\mathrm{w}$ takim procesie zawsze można wskazać drogę o skończonej długości. Podążając tą drogą proces może przejść z jednego stanu do drugiego w skończonej liczbie kroków.

Średnia liczba kroków $m_{i j}$ do pierwszego przejścia z $i$-go stanu do stanu $j$-go spełnia równanie odnowy w postaci:

$$
m_{i j}=\sum_{k \neq j} p_{i k}\left(m_{k j}+1\right)+p_{i j} .
$$

Stąd łatwo wykazać, że średnią liczbę kroków $m_{i i}$ niezbędnych do przejścia procesu do stanu $i$-go określa się równaniem: $m_{i i}=1 / \delta_{i}$. 
Controlling the operation process of the unmanned aerial system

Sterowanie procesem eksploatacji technicznej bezzałogowego systemu powietrznego

Funkcja rozkładu czasu bezwarunkowego przebywania procesu w stanie $i$-tym może być określana z zależności:

$$
F_{i}(t)=\sum_{j=1}^{N} p_{i j} F_{i j}(t)
$$

Jeżeli $\tau_{i k}$ jest średnim czasem odpowiadającym rozkładowi $F_{i j}(t)$, to z (6) można otrzymać średni czas $\tau_{i}$ bezwarunkowego przebywania procesu w stanie $i$-tym tj.:

$$
\tau_{i}=\sum_{k=1}^{N} p_{i k} \tau_{i k}
$$

Wykorzystując powyższe rozważania, rozkład prawdopodobieństwa pierwszego przejścia procesu ze stanu $i$-go do stanu $j$-go może być przedstawiony w postaci macierzy:

$$
L=\left\|L_{i j}\right\|=\left(L-L_{d q}\right)+D,
$$

gdzie D jest macierzą elementami której są średnie czasu $\tau_{i}$, zaś $L_{d q}$ jest macierzą diagonalną, otrzymana z $L$ przez zamianę elementów nie diagonalnych zerami.

Wyrażenie (8) można zapisać w postaci:

$$
L_{i j}=t_{i j} \sum_{k \neq j}^{N} p_{i k} t_{k j}+\tau_{i}
$$

Odpowiednio dla średniego czasu powrotu procesu do stanu $i$-go otrzymamy:

$$
t_{i i}=\frac{1}{\delta_{i}} \sum_{k=1}^{N} \delta_{k} \tau_{k}
$$

Średni czas pracy BSyP w stanie $j$ procesu eksploatacji technicznej między dwoma kolejnymi wejściami do stanu $i$ można opisać wzorem: $\varphi_{j i}=\frac{\delta_{j}}{\delta_{i}} \tau_{j}$, gdzie $\delta_{j} / \delta_{i}$ jest liczbą przejść do stanu j. Stad wynika, że $t_{i i}=\sum_{j=1}^{N} \varphi_{j i}$.

Prawdopodobieństwo przejścia ze stanu $i$-go do stanu $j$-go $\mathrm{w}$ czasie nie przekraczającym wartości $t$ będzie:

$$
p_{i j}(t)=p_{i j} F_{i j}(t)
$$

Wykorzystując metodę ortogonalizacji Grama-Schmidta dla skończonych procesów ze stanami komunikującymi się możemy zapisać:

$$
\lim p_{i j}(t)=\frac{\tau_{j}}{t_{j j}}
$$


dla dowolnych $t_{i}<\infty$ i dowolnych funkcji $F_{i}(t)=\sum_{j=1}^{n} p_{i j}(t)$.

Zgodnie z $[8,14]$ wyrażenie (12) przedstawia sobą współczynnik wykorzystania W stanie $j$. W szczególności, jeżeli $j$ jest celowym stanem procesu eksploatacji, to $\tau_{j} / t_{j j}$ można określić jak celową funkcję procesu eksploatacji technicznej. Celowa funkcja może być rozpatrywana jako współczynnik wykorzystania, a jego maksimum może być stosowane jako kryterium optymalności procesu eksploatacji technicznej.

Oznaczając $K_{j}=\tau_{j} / t_{j j}$ i wykorzystując wyrażenie (10) możemy zapisać:

$$
K_{j}=\frac{\tau_{j}}{\tau_{j}+\frac{1}{\delta_{j}} \sum_{k \neq j}^{N} \delta_{k} \tau_{k}} .
$$

Ponieważ $K_{j}>0$ dla wszystkich skończonych zbiorów stanów utworzonych przez ich rozwinięcie oraz $\sum_{j=1}^{N} K_{j}=1$ to $K_{j}$ jest dystrybuantą funkcji prawdopodobieństwa $P_{j k}$. $K_{j}$ jest również funkcją procesu eksploatacji technicznej i dlatego może byś stosowane jako funkcja celowa. Maksimum $K_{j}$ może być przyjęte jako jedno z kryteriów optymalności procesu eksploatacji technicznej.

\section{Modele sterowania w eksploatacji bezzałogowych systemów powietrznych}

Główne elementy systemu eksploatacji BSyP przedstawiono w tabeli 1.

Tab. 1 Elementy systemu eksploatacji BSyP

\begin{tabular}{|c|c|c|c|}
\hline \multicolumn{4}{|c|}{ EKSPLOATACJA TECHNICZNA BSyP } \\
\hline \multirow[b]{2}{*}{$\underline{\text { System eksploatacji }}$} & \multicolumn{2}{|c|}{ Procesy eksploatacji } & \multirow[b]{2}{*}{$\begin{array}{l}\frac{\text { Zarzadzanie }}{\text { eksploatacja }} \\
\underline{\underline{y}}\end{array}$} \\
\hline & $\begin{array}{l}\text { Procesy } \\
\text { sterowane }\end{array}$ & $\begin{array}{c}\text { Procesy } \\
\text { niesterowane }\end{array}$ & \\
\hline Obiekt eksploatacji & $\begin{array}{c}\text { Procesy } \\
\text { użytkowania }\end{array}$ & \multirow{4}{*}{$\begin{array}{c}\text { uszkadzalność } \\
\text { i degradacja }\end{array}$} & $\begin{array}{c}\text { modele sterowania } \\
\text { w eksploatacji }\end{array}$ \\
\hline baza eksploatacyjna & $\begin{array}{c}\text { procesy } \\
\text { obstugiwania }\end{array}$ & & diagnostyka \\
\hline kadra eksploatacyjna & \multirow{2}{*}{$\begin{array}{c}\text { logistyka } \\
\text { użytkowania } \\
\text { i obsługiwania }\end{array}$} & & \multirow{2}{*}{$\begin{array}{c}\text { badania } \\
\text { eksploatacyjne }\end{array}$} \\
\hline otoczenie eksploatacji & & & \\
\hline
\end{tabular}

System sterowania (zarządzania) w eksploatacji bezzałogowych systemów powietrznych może być zrealizowany wg schematu otwartego (rozwiniętego) (rys. 5) i zamkniętego (rys. 6). 
Controlling the operation process of the unmanned aerial system Sterowanie procesem eksploatacji technicznej bezzałogowego systemu powietrznego

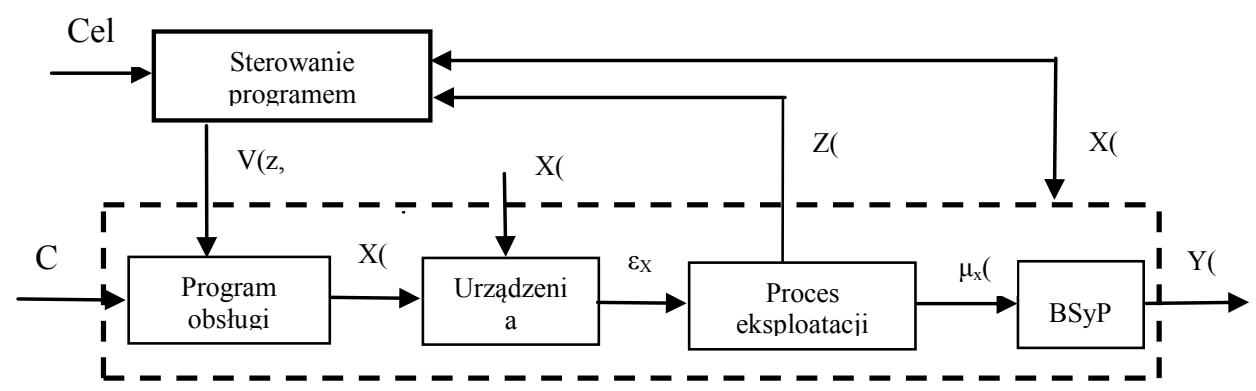

Rys. 5 Schemat otwartego (rozwiniętego) sterowania procesem eksploatacji technicznej i stanem technicznym BSyP

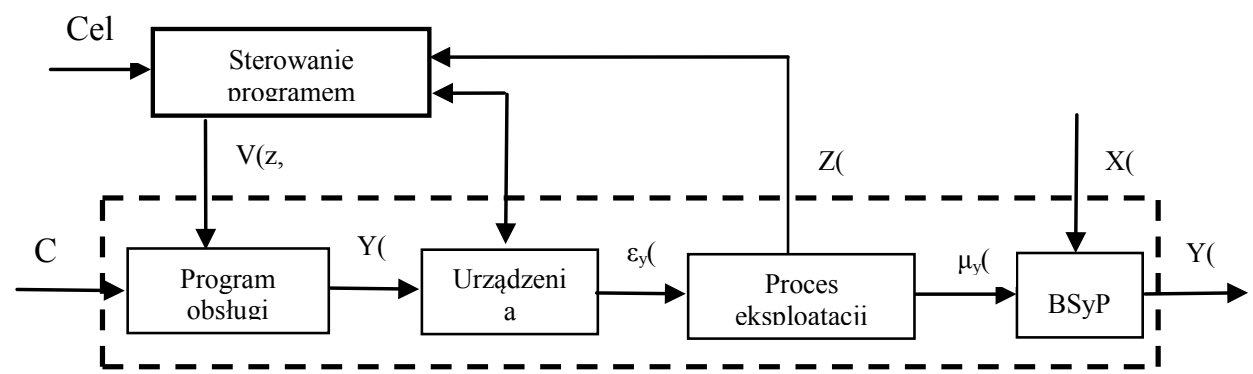

Rys. 6 Schemat zamkniętego sterowania procesem eksploatacji technicznej i stanem technicznym BSyP

Otwarty schemat sterowania realizuje zasadę sterowania (zarządzania) według wzbudzenia (parametru wejściowego) $X(t)$, powstającego pod działaniem czynników zewnętrznych. Stosowany może być w tym przypadku, gdy zewnętrzne wzbudzenia mogą być zmierzone i ustalony jest ich związek z parametrem wyjściowym $Y(t)$ charakteryzującym stan techniczny BSyP. Do schematu otwartego sterowania (zarządzania) można zaliczyć tradycyjną metodę eksploatacji opartą o wykonywanie prac profilaktycznych $\mathrm{z}$ zaplanowanymi przedziałami przepracowanego czasu pracy $X(t)=t$.

Schemat zamknięty realizuje zasadę sterowania (zarządzania) według odchyleń regulowanej wielkości (parametru wyjściowego) $Y(t)$. Wielkość regulowana $Y(t)$ jest porównywana z zadawanym oddziaływaniem $\bar{Y}(t)$. Określane jest odchylenie $\varepsilon(t)$, w zależności od którego podawane są odpowiednie oddziaływania sterujące $\varepsilon_{y}(t)$ na proces eksploatacji technicznej, a poprzez niego regulacyjne oddziaływanie $\mu_{y}(t)$ na BSyP, zmniejszające to odchylenie. W charakterze wielkości regulującej mogą być wykorzystywane wskaźniki niezawodności, na przykład, parametr strumienia uszkodzeń. Przy tym ustala się wzajemny związek między procesem eksploatacji technicznej i procesem zmiany jego stanu technicznego. 
Przy zadanym programie sterowania (zarządzania) funkcjonuje schemat zaznaczony liniami przerywanymi na rys. 5 i 6 . Do zmiany (korygowania) programu sterowania służy blok sterowania programem. Blok ten $\mathrm{w}$ zależności od zmierzonych wartości parametrów wyjściowych $\mathrm{BSyP} Y(t)$ lub wejściowych parametrów $X(t)$ i wskaźników procesu eksploatacji technicznej $Z(t)$ wykształca operator $V(z, x)$ lub $V(z, y)$ zapewniający zmianę algorytmów sterowania.

Opracowując propozycje modeli sterowania w eksploatacji BSyP autorzy oparli się na klasycznym modelu, który składa się z układu sterowanego i sterującego $[5,13]$. W związku z tym dokonując dekompozycji systemu eksploatacji BSyP możemy wyróżnić następujące podsystemy:

- system wykonywania eksploatacji BSyP, który z kolei dzieli się na system użytkowania i system obsługiwania (system sterowany),

- system kierowania eksploatacją BSyP (system sterujący).

Rozpatrując strategie eksploatacji BSyP możemy wyróżnić następujące ich rodzaje:

- eksploatacja BSyP nienaprawialnego - użytkowanie BSyP do pierwszego uszkodzenia po czym obiekt jest poddawany likwidacji (rys. 7),

- eksploatacja BSyP naprawialnego - w przypadku uszkodzenia podejmowana jest decyzja o naprawie lub likwidacji (rys. 8),

- eksploatacja BSyP z okresowym obsługiwaniem technicznym (według resursu) - założeniem tej strategii jest ściśle określony okres użytkowania, liczony na przykład ilością godziny lotu BSP, po którym następuje z góry zaplanowany program obsług (rys. 9),

- eksploatacja BSyP z ciągłym obsługiwaniem diagnostycznym (według stanu technicznego) - strategia ta polega na ciągłym monitorowaniu stanu technicznego obiektu $\mathrm{w}$ trakcie jego użytkowania i podejmowaniu decyzji dotyczących obsługiwania technicznego w zależności od danych diagnostycznych (rys. 10).

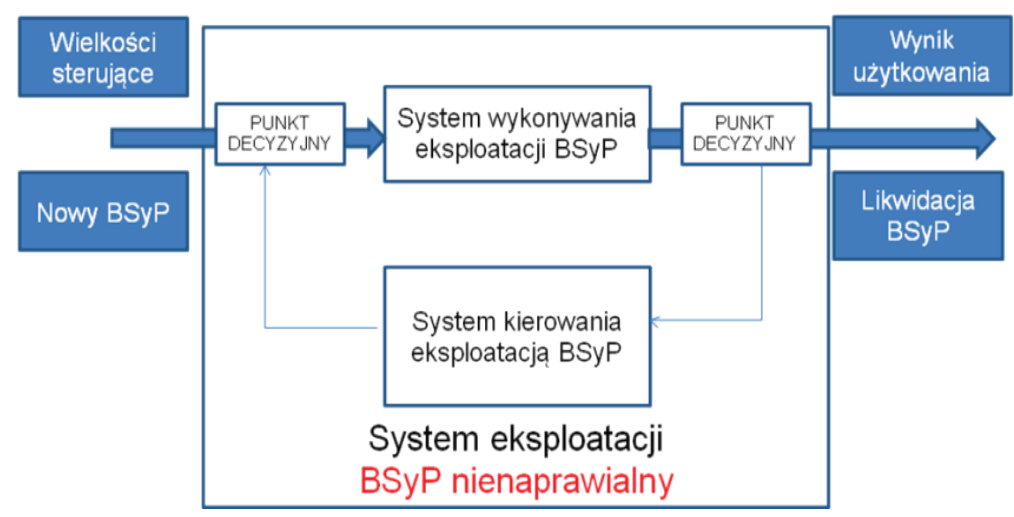

Rys. 7 Schemat modelu eksploatacji bezzatogowego systemu powietrznego nienaprawialnego 
Controlling the operation process of the unmanned aerial system

Sterowanie procesem eksploatacji technicznej bezzałogowego systemu powietrznego

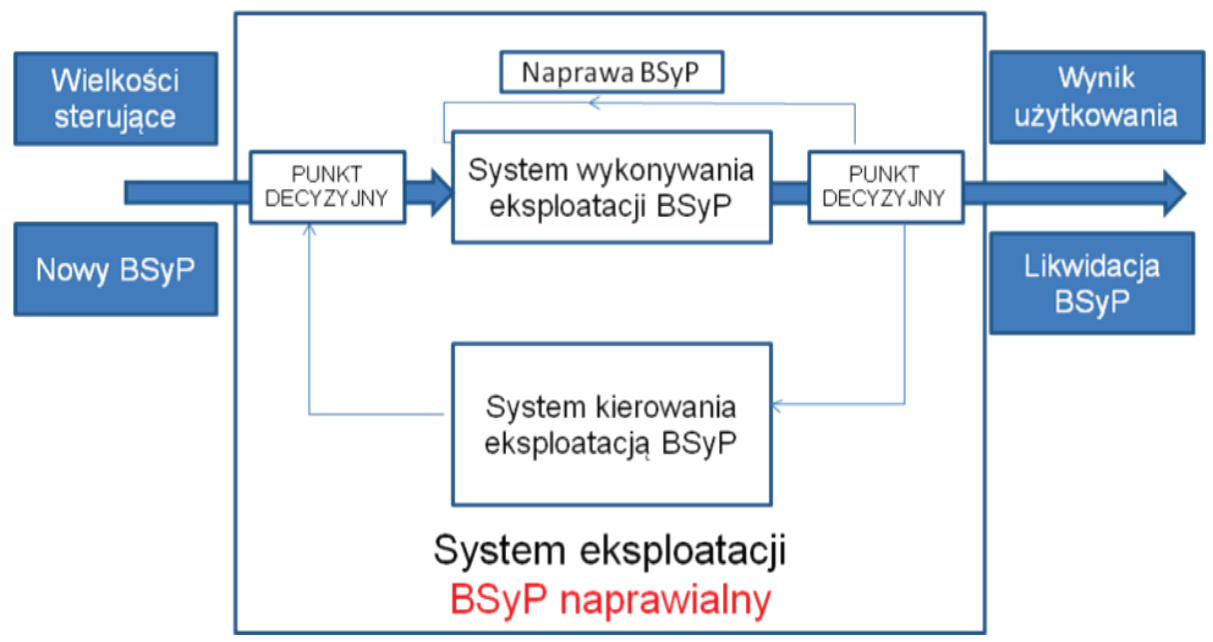

Rys. 8 Schemat modelu eksploatacji bezzałogowego systemu powietrznego naprawialnego

Przyjęcie strategii polegających na użytkowaniu BSyP do wystąpienia uszkodzenia (rys. 7 i 8) nie oznacza, że żadne obsługiwania techniczne nie są wykonywane. Elementy BSyP są poddawane konserwacji, regulacji czy też wymianie lub uzupełnianiu materiałów eksploatacyjnych. Charakterystyczną cechą takiego podejścia jest brak podejmowania działań zapobiegawczych. Modele tego typu mogą mieć zastosowanie do obiektów łatwo zastępowalnych, o stosunkowo niskim koszcie zakupu (np. cele powietrzne). Należy jednak wziąć pod uwagę, że wadami tego typu podejścia są: ryzyko związane ze skutkami uszkodzenia elementu BSyP, ograniczona możliwość zaplanowania eksploatacji oraz doraźny charakter obsługiwania.

Kolejne dwa modele sterowania w eksploatacji opierają się na założeniu, że znacznie korzystniej jest podejmować działania o charakterze zapobiegawczym niż niwelować skutki wystąpienia uszkodzenia. Strategia eksploatacji polegająca na okresowym obsługiwaniu technicznym (rys. 9) charakteryzuje się ściśle zaplanowanymi obsługiwaniami i rygorystycznie przestrzeganymi okresami użytkowania. Tego typu system eksploatacji może działać w sposób prawidłowy, kiedy zostanie zasilony informacjami związanymi $\mathrm{z}$ normatywami użytkowania i obsługiwaniami wynikającymi $z$ wiedzy i doświadczenia jego projektantów. Plany dotyczące obsługiwań technicznych opracowywane są na podstawie badań eksploatacyjnych i nie zależą od faktycznego stanu technicznego obiektu. Model tego typu charakteryzuje się łatwością kontroli eksploatacji obiektów, natomiast jego wadą są stosunkowo wysokie koszty.

Ostatnia z omawianych strategii eksploatacji (z ciągłym obsługiwaniem diagnostycznym), charakteryzuje się podejmowaniem decyzji dotyczących obsługiwań technicznych na podstawie bieżącej oceny stanu technicznego bezzałogowego systemu powietrznego (rys. 10). Możliwość rozwoju tego typu podejścia do eksploatacji pojawiła się wraz z rozwojem metod diagnostycznych oraz systemów informatycznych, które służą do pozyskiwania, gromadzenia i analizy danych pochodzących z BSyP. 


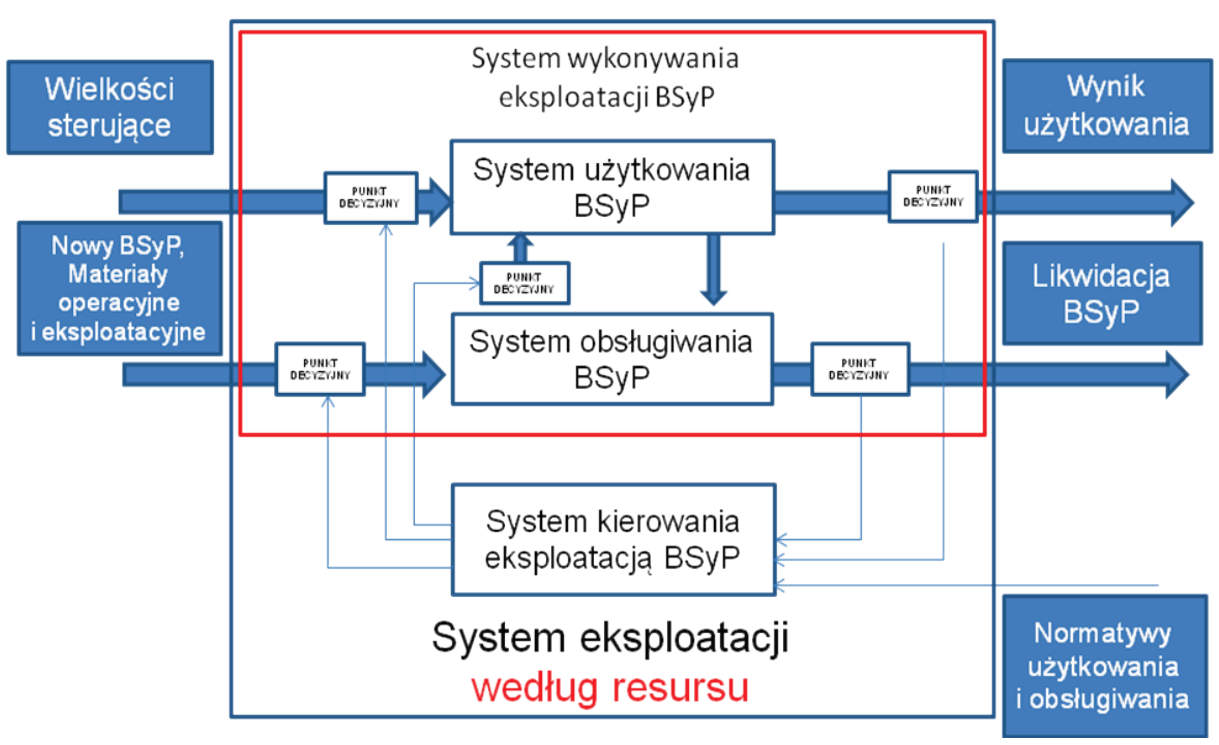

Rys. 9 Schemat modelu eksploatacji bezzatogowego systemu powietrznego z okresowym obstugiwaniem technicznym

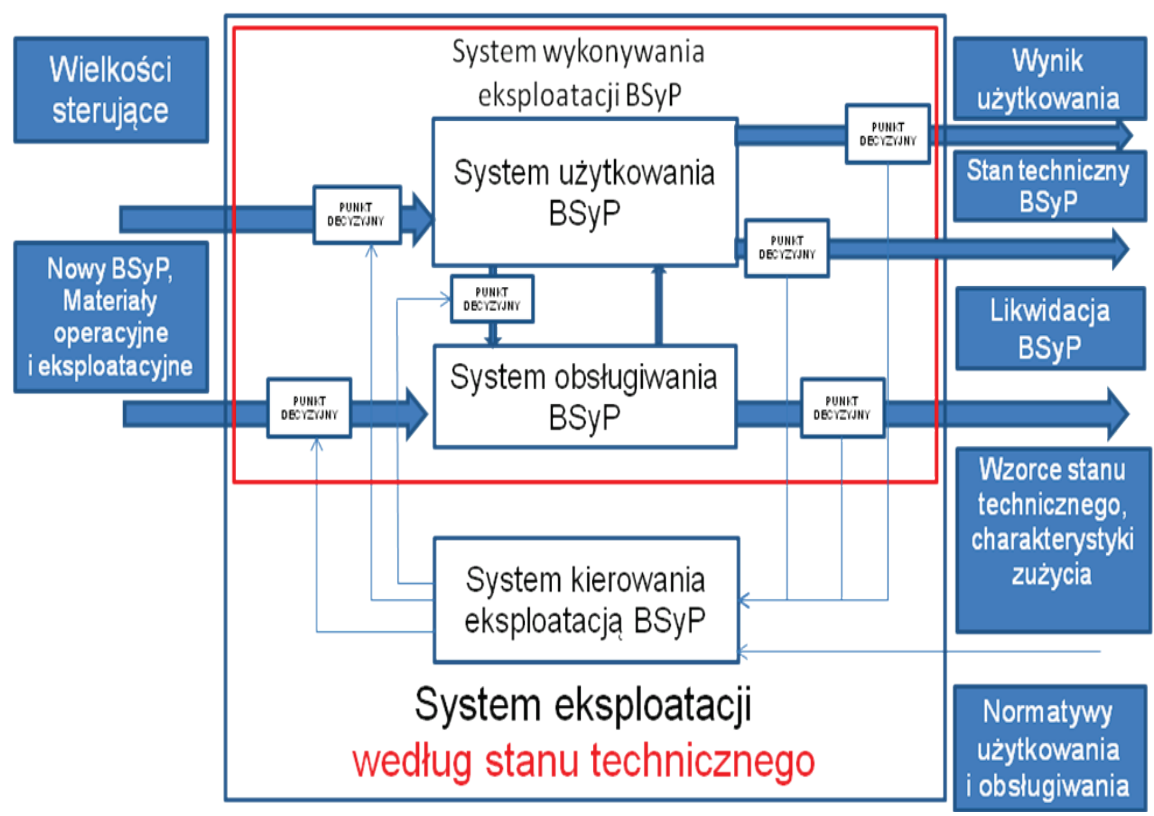

Rys. 10 Schemat modelu eksploatacji bezzałogowego systemu powietrznego z ciagtym obstugiwaniem diagnostycznym 
Controlling the operation process of the unmanned aerial system

Sterowanie procesem eksploatacji technicznej bezzałogowego systemu powietrznego

Należy nadmienić, że bezzałogowy system powietrzny eksploatowany według tego modelu powinien charakteryzować się bardzo wysoką podatnością obsługową, a personel wykonujący obsługiwania powinien być wykwalifikowany i doświadczony.

Model stwarza możliwość bardzo intensywnej eksploatacji BSyP, jednak wiąże się to ze znaczącym wzrostem kosztów związanych przede wszystkim z rozbudową systemów informatycznych.

\section{Podsumowanie}

Biorąc pod uwagę złożone wzajemne oddziaływanie znacznej liczby elementów bezzałogowego systemu powietrznego w procesie eksploatacji i wpływ na niego szerokiego widma czynników losowych, efektywność procesu eksploatacji charakteryzuje się znaczną ilością rozmaitych wskaźników. Ponieważ $\mathrm{w}$ procesie eksploatacji bezzałogowego systemu powietrznego istnieją stany jego wykorzystywania zgodnie $\mathrm{z}$ bezpośrednim przeznaczeniem, to na ich podstawie mogą być ustalone pewne funkcje celowe $\mathrm{z}$ ekstremami $\mathrm{w}$ charakterze kryterium optymalności strategii sterowania procesem.

Dlatego dla procesu eksploatacji bezzałogowego systemu powietrznego szukano minimum wskaźników pozwalających wykonać ocenę efektywności z wystarczającą dla praktyki wiarygodnością. Ze zbioru stanów eksploatacji wydzielono podzbiór stanów celów sterowania tj. stan wykorzystania zgodnie z przeznaczeniem (lot). Do oceny jakości sterowania (zarządzania) zaproponowano wykorzystanie funkcji celowej, ekstremum której może być stosowane jako kryterium optymalności strategii.

Ponadto warto dodać, że podejmowanie decyzji eksploatacyjnych zależy nie tylko od stanu technicznego BSyP, lecz również od właściwości otoczenia (środowiska, systemów współdziałających i przeciwdziałających itp.). Duża różnorodność BSP wchodzących w skład BSyP sprawia, że nie zasadne jest przyjęcie jednego, uniwersalnego modelu sterowania eksploatacją dla wszystkich typów BSyP. Co więcej z dotychczasowych doświadczeń autorów wynika, że w ramach jednego typu BSyP możliwe jest przyjęcie różnych strategii eksploatacyjnych dla każdego z elementów systemu.

Prawidłowe sterowanie eksploatacją można uzyskać wówczas, jeżeli decydentowi zostaną dostarczone zarówno informacje o ogólnych prawach rządzących rozpatrywanym systemem, jak i o jego aktualnych i przyszłych indywidualnych właściwościach. 


\section{Literatura}

[1] Bloom Neil B. Reliability Centered Maintenance (RCM). Implementation made simple. McGraw- Hill, 2005.

[2] Bengtsson M., Olsson E., Funk P, Jackson M. Technical Design of Condition Based Maintenance System. Maintenance and Reliability Conference 2004.

[3] Czaplicki J. M. Terotechnology vs. Exploatation Theory. Scientific Problems of Machines Operation and Maintenance, $\mathrm{nr} 2$ (154), 2008.

[4] Danielecki S. Eksploatacja samolotów. Oficyna Wydawnicza Politechniki Wrocławskiej, Wrocław 2004.

[5] Dawnarowicz O. Teoretyczne podstawy eksploatacji obiektów technicznych. Zeszyty naukowe Politechniki Gdańskiej. Gdańsk 1993.

[6] Domańska J., Domański A., Augustyn D.R., Klamka J. A RED modified weighted moving average for soft real-time application. International Journal of Applied Mathematics and Computer Science, Vol. 24 (3), pp. 697-707, 2014.

[7] Gasiński L. Problemy jakości w eksploatacji maszyn i urządzeń. Problemy Eksploatacji, Z.4, 1997.

[8] Grabski F., Jaźwiński J. Funkcje o losowych argumentach w zagadnieniach niezawodności, bezpieczeństwa $i$ logistyki. Wydawnictwa Komunikacji i Łączności, Warszawa 2009.

[9] Jurlewicz T., Skoczylas Z. Algebra liniowa 2: definicje, twierdzenia, wzory. Oficyna Wydawnicza GiS, Wrocław 2005.

[10] Landowski B., Woropay M. Symulacja procesu eksploatacji obiektów technicznych poddanych obstudze profilaktycznej. XXXI Szkoła Niezawodności, Szczyrk 2003.

[11] Legutko S. Eksploatacja maszyn. Wydawnictwo Politechniki Poznańskiej, Poznań 2007.

[12] Lewitowicz J. Podstawy eksploatacji statków powietrznych. Tom 3. Systemy eksploatacji statków powietrznych. Wydawnictwo Instytutu Technicznego Wojsk Lotniczych, Warszawa 2006.

[13] Niziński S., Żółtowski B. Zarządzanie eksploatacja obiektów technicznych. Wydawnictwo MARKAR, Zielonka 2002.

[14] Pursell L., Trimble S. Y. Gram-Schmidt Orthogonalization by Gauss Elimination. The American Mathematical Monthly. Vol. 98 (6), pp. 544-549, 2017. 
Controlling the operation process of the unmanned aerial system

Sterowanie procesem eksploatacji technicznej bezzałogowego systemu powietrznego

[15] http://www.faa.gov/about/initiatives/maintenance_hf/library/documents/media /human_factors_maintenance/maint_uav_nasa.pdf.

[16] http://hsi.arc.nasa.gov/publications/UAV_interimreport_Hobbs_Herwitz.pdf.

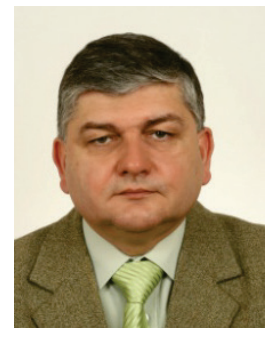

Dr hab. in.. Leszek Utanowicz, absolwent Wojskowej Akademii Technicznej $w$ zakresie samolotów i śmigtowców. Wieloletni pracownik naukowo-badawczy w Instytucie Technicznym Wojsk Lotniczych. Pracuje w Zakładzie Samolotów i Śmigłowców na stanowisku adiunkta. Główne kierunki działalności naukowej to: lotnicze napędy hydrauliczne $i$ ich systemy sterowania oraz regulacji, niezawodność $i$ eksploatacja systemów technicznych, badania naziemne $i$ w locie statków powietrznych. Jest autorem $i$ wspótautorem 62 prac naukowych (monografii, artykułów, referatów na konferencjach $i$ seminariach naukowych). Kierownik kilku projektów badawczo-rozwojowych.

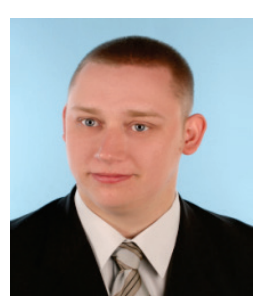

Dr ini. Pawel Szczepaniak - absolwent Wydziatu Mechanicznego Wojskowej Akademii Technicznej w Warszawie, dyscyplina naukowa: Budowa $i$ Eksploatacja Maszyn. Specjalizuje się $w$ zagadnieniach inżynierii eksploatacji oraz diagnostyki systemów plynowych techniki lotniczej. Pracuje na stanowisku adiunkta $w$ Zakładzie Samolotów i Śmigłowców Instytutu Technicznego Wojsk Lotniczych w Warszawie.

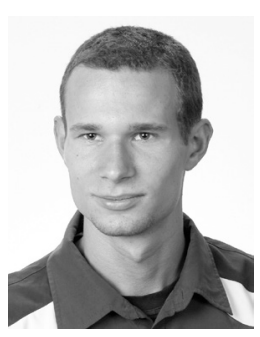

Mgr inz. Michat Jóźko - Absolwent Wydzialu Inżynierii Produkcji Politechniki Warszawskiej. Zajmuje się zagadnieniami zwiazanymi z diagnostyka lotniczych instalacji hydraulicznych. Pracuje na stanowisku starszego specjalisty w Pracowni Badań i Konstrukcji Systemów Hydroenergetycznych Techniki Lotniczej, w Zakładzie Samolotów i Śmigłowców Instytutu Technicznego Wojsk Lotniczych w Warszawie. 